\title{
Geological, geophysical and geochemical structure of a fault zone developed in granitic rocks: Implications for fault zone modeling in 3-D
}

\begin{abstract}
The structure of a fault zone developed in granitic rocks can be established on the basis of the spatial variability of geological, geophysical and geochemical parameters. In the North Fault of the Mina Ratones area (SW Iberian Massif, Spain), fault rocks along two studied traverses (SR-2 and SR-3 boreholes) exhibit systematic changes in mineralogy, geochemistry, fabrics and microstructures that are related to brittle deformation and alteration of granite to form cataclasite and subsequent gouge. The spatial distribution and intensity of these changes suggest a North Fault morphology that is consistent with the fault-core/damage-zone model proposed by Chester et al. (1993) to describe a fault zone architecture. North Fault damage zone thickness can be defined by the development of mechanically related mesoscopic faults and joints, that produce a Fracture Index $(\mathrm{FI})>10$. High FI values are spatially correlated with relative low seismic velocity zones $\left(\mathrm{V}_{\mathbf{P}}<5 \mathrm{~km} / \mathrm{s}\right.$ and $\mathrm{V}_{\mathrm{S}}<2.5 \mathrm{~km} / \mathrm{s}$ in the well-logs), more probably related to a high concentration of fractures and geochemical alteration produced by meteoric water-granite interaction along fault surfaces. This correlation is the base of a geostatistical model proposed in the final part of this study to image the fault zone architecture of a granitic massif.
\end{abstract}

Keywords Fault zone deformation - Seismic velocity . Geochemical alteration - Geostatistical modeling - SW Iberian Massif

\footnotetext{
J. Escuder-Viruete $(*) \cdot C$. Pérez-S•ba

Dept•. Petrøløgía y Geøuímica,

Universidad Complutense,

28040 Madrid, Spain

e-mail: escuder@e.ucm.es

Tel.: +34-91-3945014

Fax: +34-91-5442535

R. Carbønell · D. Martí · A. Pérez-Estaún Inst. Ciencias de la Tierra Jaume Almera-CSIC.,

Lluís S•lé i Sabarís s/n.,

08028 Barcelona, Spain
}

\section{Introduction}

Brittle fault zones are lithologically heterogeneous and structurally anisotropic discontinuities in the upper crust. Evaluating the mesoscopic structure of fault zones at scales between one meter and hundreds of meters is important for a variety of applications, including hydrogeology, hydrocarbon migration, toxic and non-toxic waste isolation, ore deposits, earthquake nucleation and propagation, and the rheological/mechanical behavior of faults (Barton et al. 1988; Forster and Evans 1991; Bruhn et al. 1994; Caine et al. 1996; Fisher and Knipe 1998; Li et al. 1998; Schulz and Evans 1998, 2000; Ohtani 2000).

Following a conceptual model of fault zone architecture, faults can be divided into two distinct components: the fault core, where most of the displacement is accommodated, and the damaged zone, that is mechanically related to the growth of the fault zone (Chester and Logan 1987; Smith et al. 1990; Forster and Evans 1991; Caine et al. 1993, 1996; Scholz and Anders 1994). Fault core materials are commonly composed of one or more structural elements such as anastomosing slip surfaces, clay-rich gouge, cataclasite and fault breccias. Damage zone structures are mechanically related fracture sets, small faults, veins and joints. The fault core and the damage zones are surrounded by relatively undeformed protolith. The relative shapes and sizes of each of these structural components will vary from fault to fault and within a fault system and there may be more than one fault core or principal slip surface within a fault zone (Chester and Logan 1987; Chester et al. 1993; Evans and Chester 1995; Schulz and Evans 1998, 2000). From a lithologic, structural and hydrogeological point of view, fault core, damage zone and undeformed protolith are distinct units that reflect the material properties and deformation conditions within a fault zone (Caine et al. 1996; Schulz and Evans 1998, 2000). This architecture controls the physical properties of fault zones that include porosity, permeability, fluid flow, their mechanical behavior and geophysical/geochemical signatures (Bruhn et al. 1994; Evans and Chester 1995; Wintsch et al. 1995; 
Evans et al. 1997; Unsworth et al. 1997; Schulz and Evans 1998, 2000).

Fault zones are only partly accessible to direct observations and, for this reason, a wide variety of geophysical methods have been employed to image fault zones and related brittle strain. For example, seismic reflection, magnetotelluric and tomographic studies suggest that large-displacement strike-slip faults consist of a relative low-velocity zone as thick as $100-200 \mathrm{~m}$ to $2-3 \mathrm{~km}$. With the exception of high resolution seismic tomography (Eberhart-Phillips and Michael 1993; Scott et al. 1994; Holliger and Robertsson 1998; Morey and Schuster 1999; Cheng et al. 2001; Cosma et al. 2001; Martí et al. 2002a, $2002 \mathrm{~b}$ ), available information of the shallow subsurface is commonly limited to one-dimensional (1-D) data arrays (core descriptions and geophysical well logs) and continuous two-dimensional (2-D) vertical seismic profiles, which generally have vertical and horizontal resolutions no better than upward of 5 and $25 \mathrm{~m}$, respectively. Consequently, adequate characterization of the morphology and dimensions of each structural component of the fault zones in local scale studies is frequently hindered. To solve this problem, the investigation of some geological or geophysical properties has been proposed to define indirectly the extension and spatial variability of the fault zones, such as the macroscopic brittle deformation, geochemical alteration produced by fluid-rock interactions, mineralogical changes in fault-rocks or microscopic deformation and textures (Chester et al. 1993; Bruhn et al. 1994; Evans and Chester 1995; Evans et al. 1997; Unsworth et al. 1997; Schulz and Evans 1998, 2000; Manatschal et al. 2000; Tanaka 2001). But the extension of a given fault zone depends upon the type of attribute used to describe it, as well as the scale of observation (Ito et al. 1998; Schulz and Evans 2000). At scales between one meter and hundreds of meters, for example, there exist difficulties in reconciling the thickess of a faultrelated deformation and alteration with their geophysical signature, since geophysical methods normally image fault zones one or two orders of magnitude higher (Feng and McEvilly 1983; Mogi et al. 1991; Eberhart-Phillips and Michael 1993; Wintsch et al. 1995; Unsworth et al. 1997; Schulz and Evans 2000).

In this paper, the distribution of fault-rocks, brittle structures, deformation mechanisms, whole-rock geochemistry and changes in the P- and S-wave seismic velocities are examined across the North Fault, a decametric thick fault zone developed in the Albalá Granitic Pluton. These data and previous investigations are combined to evaluate how a fault zone may be defined on the basis of a combination of these characteristics and imaged by direct and indirect methods. North Fault-related deformation is observed at several scales, from mesoscopic (outcrop) to microscopic (petrographic and scanning electron microscope). Fracture density, structural data, and evolution of fault-rock type along the damage zone are recorded from two boreholes (traverses) perpendicular to the North Fault zone. Geochemical, microstructural and mineralogical variations within the fault zone are also described and briefly interpreted. Structural and geophysical results and implications are discussed in terms of fault zone width and morphology. The results of this study are finally used to build a geostatistical model of the 3-D fault zone architecture that permits the quantitative structural classification of the Mina Ratones granitic rock massif. This work forms part of a multidisciplinary project carried out for the environmental restoration of old uranium mines supported by ENRESA (Spanish nuclear waste management company).

\section{Geological setting}

The Albalá Granitic Pluton

The Albala Granitic Pluton is located in the southwest sector of Iberian Massif (Central-Iberian Zone), which represents the westernmost segment of the European Variscan Belt (Pérez Estaún et al. 1991). The pluton is a concentric zoned body, elongated in a N-S direction, with porphyritic biotite granites in the rim and fine-grained two-mica leucogranites in the core (Fig. 1). Major, trace and rare-elements suggest that magmatic rocks form a continuous sequence ranging from granodiorites through monzogranites, granites to leucogranites (Gumiel and Campos 1998; Pérez Soba et al. 2001). Rb-Sr whole rock ages indicate intrusion ages of $302 \pm 4$ Ma (Pérez Estaún et al. 2002). The Albalá Granitic Pluton was emplaced in the epizonal rocks of the Schist-Grauwacke Complex (Upper Proterozoic to Lower Cambrian) and Lower Ordovician fossiliferous formations (Gil and Pérez Rojas 1982). In these materials, a Variscan S1 schistosity is recognized, that presents in this sector a N-S to NNE-SSW trend with subvertical dip. S1 schistosity appears folded by a system of subvertical ductile shear zones with NW-SE trend and sinistral displacement, related to a second E-W directed shortening phase. The ensemble is also deformed by a set of ductile-brittle and brittle wrench structures, related to a third late-Variscan N-S to NNE-SSW directed subhorizontal shortening (Castro 1986; Díez Balda et al. 1990). The regional distribution of magmatic fabrics in the Albalá Granitic Pluton indicate that their emplacement was coeval with this third late-Variscan phase (Escuder Viruete et al. 1999).

Sn, W, As, P and U enrichment and mineralization events present in late-magmatic dykes are genetically related with the most differentiated leucogranitic hosted rocks (Reguilón 1988; Pérez del Villar et al. 1999). The origin of the uranium mineralization comes from the remobilization of this element, present in the host leucogranite in the form of accessory uraninite. The mineralizing fluids filled NNE-SSW dykes and fractures organized in a pattern, which is consistent with the strikeslip tectonics of the third late-Variscan phase (Castro 1986; Sanderson et al. 1991; Escuder Vinete 1999; Pérez Estaún et al. 2002). Mina Ratones is located in the central-southern sector of the Albalá Granitic Pluton (Fig. 1). Two main NNE-SSW orientated subvertical 
Fig. 1 Geølegical map of A1bala Granitic Pluton with location of the Mina Ratones area (Escuder Viruete and Perez Estaún 1998; Pérez Estaún et al. 2002)

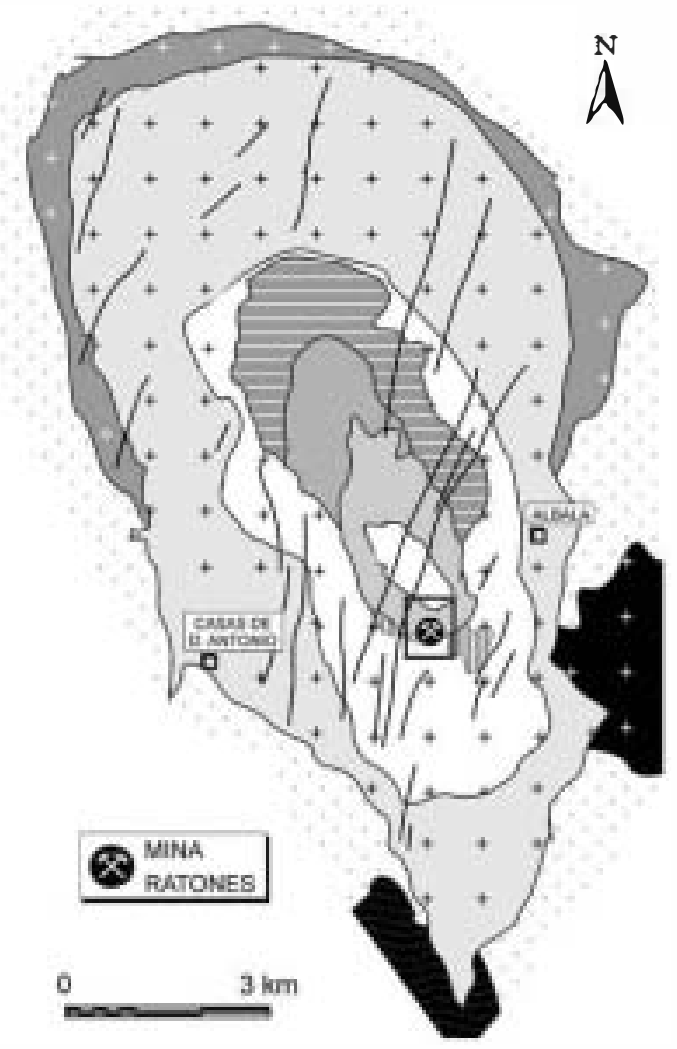

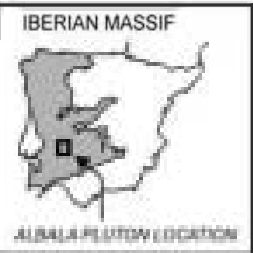

LEGEND

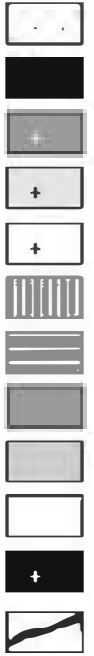

Jpper Proterozojic

Lower Ordovician

Coarse-grained two-mica granite

Megacrystic biotite granite

Porphyritic biotıte granite

Fine to medium-grained granite

Medium-grained Jeucogranite

Medium-grained granite

Medium-grained biotite teucogranite

Anhedral fine-grained teucogranite

Montanchez granites

Main dykes and filons filons (27 and 27' Dykes), with quartz, pitchblende, coffinite and black Fe-Mn oxides, were mined between 1955 and 1974. The amount of extracted minerals were approximately $125,000 \mathrm{t}$ with a grade of $0.227 \%$ uranium oxides (Arribas 1962; Martínez and Ramírez 1966).

The post-Variscan stuctural evolution of the Albala Granitic Pluton has been established on the basis of fault kinematics and palaeostress analysis in superficial outcrops (Escuder Viruete and Pérez Estaún 1998; Pérez Estaún et al. 2002). This evolution includes three episodes of brittle deformations related to different stress-field configurations, which cut and reactivate ductile and ductile-brittle late-Variscan structures. The first postVariscan episode is extensional and produces the intusion of Jurassic subverical diabasic dykes, aligned following a NNE-SSW wend. The constant trend of these dykes at regional scale indicates that $\sigma_{3}$ was subhorizontal and WNW-ESE to NW-SE directed. The second postVariscan (Cenozoic) episode is characterized by the development of a system of conjugated swike-slip faults and associated mid to low-angle thrusts. In the Mina Ratones area, swike-slip faults can be geomerically grouped in two sets of different development: the sinistral NNE-SSW to ENE-WSW and the conjugate dexwal N-S to NW-SE (Fig. 2). Cenozoic thrust faults show a E-W to ENE-WSW trend and a $\mathrm{N}$-directed sense of movement. The kinematics of all strike-slip and thrust faults suggest that $\sigma_{1}$ was subhorizontal and NNE-directed during this phase, characterized by a wrench stress configuration with $<\mathbf{R}<\mathbf{0 . 5}$ and normally $\mathbf{R}=\mathbf{0} .38-44(\mathbf{R}=02-03 / \sigma 1-$ o3; Pérez Estaún et al. 2002). In some fault core rocks of the strike-slip faults there is secondary U-mineralization generated by remobilization of uranium in the fluid-phase through fault network, during the reactivation of NNESSW to NE-SW late-Variscan dykes as Cenozoic strikeslip faults. The third post-Variscan episode produced the parial reactivation of the previous structures and dykes as normal and normal-slip faults. The kinematic of fault system deduced from striated slickensides in the fault plane are compatible with a extensional stress field (R> .82), with a subhorizontal and NNW- to N-directed $\sigma_{3}$, opposite to the previous Cenozoic shortening, and even with a late radial extension (Fig. 2; Escuder Viruete and Pérez Estaún 1998; Pérez Estaún et al. 2002). Late normal fault cores are characterized by microbreccias, foliated cataclastic rocks and slightly colored gouges.

Fault zone distribution in the Mina Ratones area

Fault zone distribution in the Mina Ratones area has been established on the basis of field geology, structural analysis, seismic experiments, four drilled inclined cores (SR-1 to 4) and sonic well-log data (Carbonell et al. 1999; Escuder Viruete and Pérez Estaún 1998; Escuder Viruete 1999; Jurado 1999; Marrí et al. 2002a, 2002b; Pérez Estaún et al. 2002). The main structures identified are the North Fault, the South Fault and the 27 and 27' Dykes (Fig. 2). Other relevant brittle stuctures of minor size are the 474,476 and 285 Faults. 
$\overline{\text { Macro and mesoscopic structure of North Fault zone }}$

Fault zone structural analysis

A structural analysis of North Fault zone was realized in surface outcrops and in two traverses across the structure recovered as borehole cores (Fig. 2). Well axes are approximately inclined $20^{\circ}$ to the NNW trend in the SR-2 and $10^{\circ}$ to the $\mathrm{N}$ trend in the SR-3. For the surface structural analysis, high quality exposures where rocks are cut by one or several joint and fault sets were selected in the Mina Ratones area. In all outcrops, structural discontinuities were measured along two scanlines $10-35 \mathrm{~m}$ in length that cross one another at nearly perpendicular angles. Along scanlines, the point of intersection of the fractures with the scanline is recorded and, in the case of faults, throw, dip-direction, dip-angle and vector of movement were also recorded for further geometric and kinematic analysis. Lower hemispheric stereographic projections of the measured fracture orientations in surface are shown in Fig. 2a-e. As observed in the figure, the two main NNE-SSW to ENE-WSW and the conjugate N-S to NW-SE sets of cartographic fault zones are also characteristic in the population of the small scale faults. In the boreholes drilled at Mina Ratones, the acoustic records obtained from ultrasounds (borehole televiewer, BHTV) provided an oriented image of the well wall (Jurado 1999), where dip-direction and dipangle of joint and fault were determined from the sinusoidal trace of the plane (Fig. $2 \mathrm{~h}, \mathrm{i}$ ). The vector and sense of movement of small scale faults was determined from a variety of kinematic indicators in the extracted oriented core.

Traverse 1 and 2 of the North Fault zone are obtained from SR-2 and SR-3 well cores, respectively. The hanging wall section of the North Fault in the SR-2 is characterized by the presence of a foliated gouge in the core bordered by a fractured and faulted damage zone up to $8-9 \mathrm{~m}$ thick. The individual faults within the damage zone of the North Fault are narrow, 1 to $10 \mathrm{~cm}$ thick, and composed of variably foliated cataclasite and fine-grained gouge. Contacts between cataclasite and undeformed granite are sharp along the narrow faults. Wider faults $(<70 \mathrm{~cm})$ contain reddish fine-grained gouge and whitish cataclasite, that display a crude to well-defined foliation defined by elongate lozenges and irregular zones of relatively less-deformed protolith. As is observed in drill cores and BHTV record, most of the minor faults are dipping a low-angle $\left(\left\langle 30^{\circ}\right)\right.$. North Fault core have a general low-angle dip. Whole rock samples described later in this paper were collected along traverses 1 and 2 of the North Fault zone, and include fault core gouge, damage zone sections and undeformed granitic protolith.

\section{Small fault density data}

An observed fact in many fault zones is that fracture density in the fault damage zone increases toward the central fault core (Goddard and Evans 1995; Little 1996; Schulz and Evans 1998, 2000). This fracture density can be quantitatively defined by a Fracture Index (FI, in $\mathrm{m}^{-1}$ units), or number of structural discontinuities present by unit length of scanline in the outcrop ( $\mathrm{La}$ Pointe and Hudson 1985; Narr and Suppe 1991; Engelder et al. 1997). Based on the probable presence of a fracture gradient perpendicular to a fault core, FI measures in discrete domains can be used to characterize fault zone architecture and its spatial variability using geostatistical methods (Escuder Viruete et al. 2001). In the Mina Ratones area, FI values were estimated in several surface outcrops (limited in number and distribution) and in two drilled subvertical cores (SR-2 and 3; Fig. 2), where FI is in the last case the number of structural discontinuities present by unit length along the well-axis. BHTV images permit to discriminate the tectonic fractures from the fractures induced by core perforation and extraction. However, traditional fracture spacing measures have inherent geometric biases, which can lead to inaccurate representations of the true fracture pattern. These linear sampling biases were eliminated here utilizing a trigonometrical correction following Terzaghi's (1965) approach and the techniques included in La Pointe and Hudson (1985). From fracture spacing data unbiased fundamental rosettes and stereograms of fracture frequency were compiled, which more closely approximate the true geometry of the fault zone system and allow one to compute the overall fracture intensity in each outcrop or core section.

Figure 3 shows the FI $\log$ along the SR- 3 borehole. The distribution of the FI values in the SR-3 allows to identify three fault zones, located in the depth intervals: (Z1) 418-413 m, (Z2) 395-389 m, and (Z3) 323-305 m, respectively. $\mathrm{Z} 1$ and $\mathrm{Z} 2$ zones correspond to high-angle strike-slip faults and Z3 zone includes the North Fault, whose central core is located at the depth of $315 \mathrm{~m}$. Loss in the material recovered from this central zone explains a local underestimate of the FI. In the SR-2, only a zone of greater FI related to the North Fault zone is observed. In general, there is a FI increase from the relatively undeformed granitic protolith to the central fault core, and low FI intervals correspond to less fractured granite. As is shown in Fig. 3, the damage zone is present in both sides of the fault core in the two traverses across the North Fault and characterized by high Fracture Index values $\left(\mathrm{FI}>10 \mathrm{~m}^{-1}\right)$. FI data suggest a damaged zone thickness of approximately $8-15 \mathrm{~m}$, although damage zone thickness is not the same on both sides of the fault core, neither the spatial extent nor amount of brittle deformation. However, in both traverses fracture density increases toward the fault core and the greatest FI measured are adjacent to the fault core. This fracture density gradient has been observed in many fault zones (Goddard and Evans 1995; Little 1996; Engelder et al. 1997; Schulz and Evans 1998, 2000; Escuder Viruete et al. 2001). 
Fig. 3 Geølogical, seophysical and seochernical structure of the North Fault at Mina Ratones in the SR-3 borehole. Relationships between Fracture Index (m , fracture intensity), $\mathbf{P}$-wave velocity $l \bullet \xi(\mathrm{km} / \mathrm{s})$, S-wave veløcity $\log (\mathrm{m} / \mathrm{s})$, geochemical alteration ( $R$ red; $G$ green; $W$ white), clay neoformation (determined by DRX analysis) and nature of the fracture filling. $F e$ $\mathrm{Fe}-\mathrm{Mn}$ oxides and oxyhidroxides; Chl chlorite; Fto feldspar corrosion and disselution; $\mathbf{e t}$ quartz crystallization; $E p$ epidote; Clay clay mineral neof mation; Ca carbonate crystallization; Py secondary pyrite crystallization

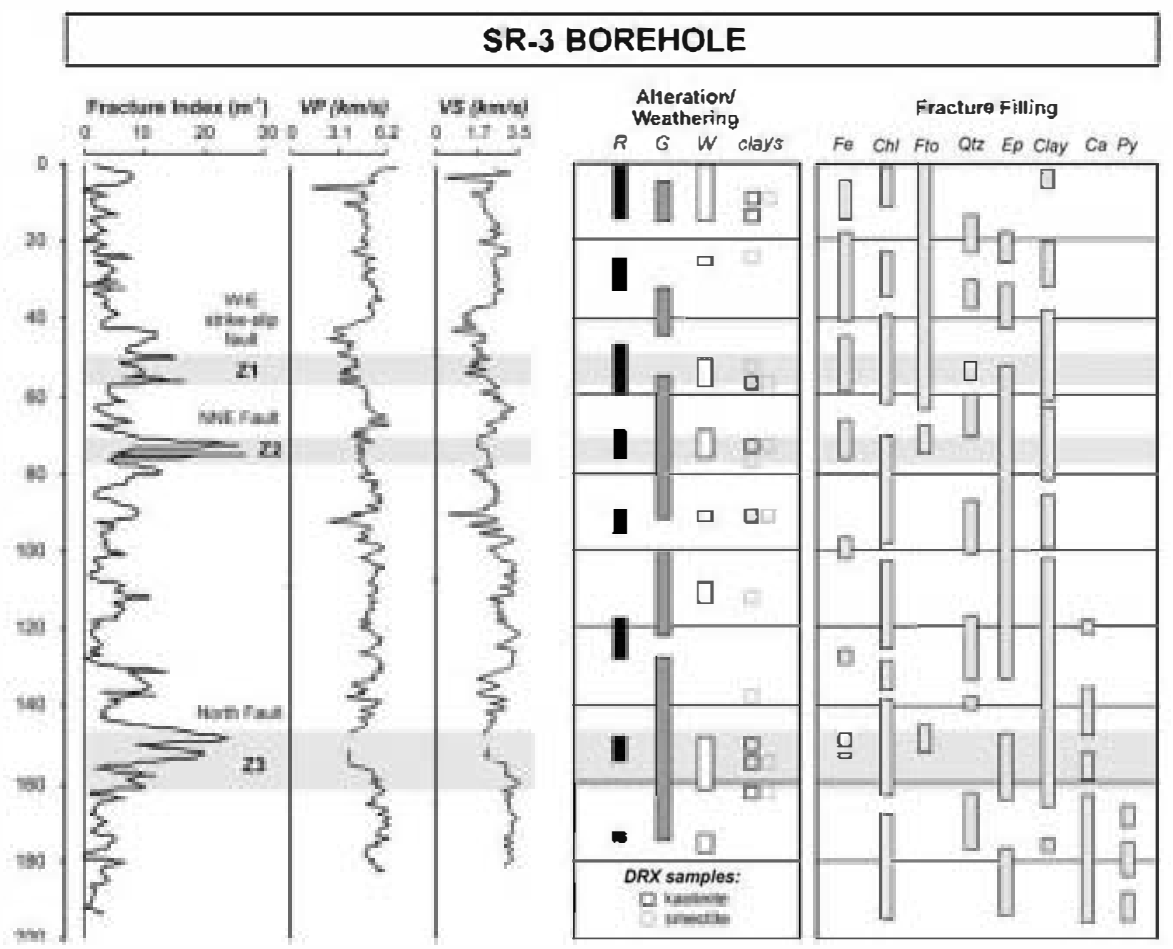

P- and S-wave seismic velocity data

Fault zones can be imaged in a granitic massif by its physical properties. For this reason, measurements of $P$ - and S-wave velocities were performed in the Mina Ratones area with conventional and full waveform sonic probes (Jurado 1999; Martí et al. 2002a, 2002b). Figure 5 shows the $P$ - and $S$-wave velocity $\log \left(V_{P}\right.$ and $\left.V_{S}\right)$ in the SR-2 and SR-3 wells. The average velocity for both boreholes is approximately $5.3 \mathrm{~km} / \mathrm{s}$ and $2.8 \mathrm{~km} / \mathrm{s}$ for the $V_{P}$ and $V_{S}$, respectively. Some incorrect records obtained in the North Fault core have been omitted. The velocity logs reveal two facts: (1) the velocity has a general tendency to increase slightly with increasing depth; and (2) relatively low velocity zones are identified as corresponding to volumes of granite which are more fractured (FI $>10 \mathrm{~m}^{-1}$ ), or altered (see bellow), less compact when compared with the relatively higher velocities of the surrounding rock volume. In general, fault zones are characterized by $V_{p}<5 \mathrm{~km} / \mathrm{s}$ (between 4.2 and $4.8 \mathrm{~km} / \mathrm{s}$ ) and $V_{S}<2.5 \mathrm{~km} / \mathrm{s}$, and the undeformed granite by $V_{p}>5 \mathrm{~km} / \mathrm{s}$ and $V_{S}>3.0 \mathrm{~km} / \mathrm{s}$. This velocity variation is due to porosity, fracture density and mineralogical/chemically altered areas, which will affect granite composition and fluid content. Low $V_{P}$ and $V_{S}$ zones are correlated with altered granite and cataclasite (see below), which have a relatively high FI. In this sense, Marti et al. (2002a, 2002b) propose an empirical linear correlation between $V_{P}$ or $V_{S}$ and FI values. Therefore, $V_{P}$ or $V_{S}$ variations recorded in the logs permit one to establish indirectly the existence and the thickness of a fault zone developed in granitic rocks. This correlation is the base of the geosta- tistical model of fault zone architecture in the Mina Ratones area built in a later section.

\section{Microscopic structure of North Fault zone}

Fault-rocks

In the drilled cores extracted at Mina Ratones, four lithologies can be distinguished associated with the North Fault: granite (host rock), hydrothermally altered granite, cataclasite and gouge.

Granite. The footwall and the hanging wall of the North Fault mainly consist of a late-Variscan undeformed peraluminous granite (Fig. 2). Petrographically, the granite is a medium-grained bionte+muscovite leucogranite (Perdices facies) and is composed of 25-30\% quartz, 20 $30 \% \mathrm{~K}$-feldspar, 10-15\% plagioclase, 6-8\% biotite and 1-10\% muscovite. Primary accessory minerals are apaite, ilmenite, monazite, zircon, uraninite and allanite. The texture is medium grained phaneritic with microcline phenocrysts reaching $5-8 \mathrm{~mm}$. A weak magmatic flow foliation defined by the preferred orientation of microcline phenocrysts and biotite is often developed. A more extensive description of the Albalá Granitic Pluton lithologies is given in Gumiel and Campos (1998), Escuder Viruete and Pérez Estaún (1998) and Pérez Soba et al. (2001) and Pérez Estaún et al. (2002).

Hydrothernally altered granite. Examination of thin sections collected in surface outcrops and drilled cores shows that no part of the Mina Ratones granite is completely free of a green (chlorite-epidote-sericite) hydrothermal alteration related to late-magmatic fluid 
activity. Primary igneous minerals are variably involved in this type of alteration: chlorite replaces biotite, sericite replaces $\mathrm{K}$-feldspar and a very fine-crystalline albite+epidote \pm calcite saussuritic assemblage replaces plagioclase. This alteration was developed in the greenschist facies metamorphic conditions and their development is spatially related to intrusion of NNE-SSW-oriented quartzapatite \pm calcite late-Variscan subvertical dykes.

Cataclasite. Toward the North Fault core, the transition from the undeformed granite to intensely deformed cataclasites and gouges is gradational and occurs in the damage zone over a distance of several meters. With increasing strain in the damage zone the network of fractures becomes increasingly connected and small-scale faults occur. Areas of high brittle deformation are characterized by cataclasite formation with a matrix/clast ratio between $10-60 \%$ and foliation development. The mineralogical composition of the cataclasites consists of varying proportions of fractured minerals and aggregates, originating from the host granite, and alteration products of feldspar and biotite, such as chlorite, clay minerals, and minor calcite and quartz. The fracture network in some cataclastic intervals is characterized by red-colored selvages, generally a few centimeters wide, occurring beside the fracture planes. This reddish-brown zone is related to a late Fe-oxide and oxyhydroxide staining within slightly altered feldspars and along microfractures. Some cataclasites have a white 1-5-mm-thick, bleached subparallel zone, caused by the white color of the completely altered plagioclase. In the fault core, the fabric of the cataclasites changes from microbreccia to a fault gouge.

Gouge. The core of the North Fault zone is formed by 2-3 bands of a continuous gouge, few decimeters thick. The gouge interval separates variably brecciated granite and cataclasite in the hanging wall from weakly deformed granite in the footwall. The contact between the gouge and the cataclasite is sharp. The gouge is characterized by a matrix-supported fabric with a matrix/clast ratio that varies between 60 and $95 \%$. The gouge is dominantly composed by very fine-grained clay minerals, with variable amounts of feldspar and quartz rounded clast, and elongated fragments of muscovite and chloritized biotite showing a preferred orientation. The clast of major size in the gouge consists mainly of fragments of cataclasite. Determined by XRD analyses, the gouge matriz $(<2 \mu \mathrm{m}$ fraction) is composed of kaolinite, smectite, chlorite, very subordinate calcite and Fe-oxides and oxyhydroxides, than usually form red-colored zones within high strain zones.

Fracture fillings. Figure 6 shows the relationships between FI, $V_{\mathbf{P}}$, type of geochemical alteration and minerals filling fractures and small $(<1 \mathrm{~mm}$ thick) veins observed in the core of the SR-3 well. As is observed in the figure, red staining by $\mathrm{Fe}$-oxides and oxyhydroxides and the white alteration of feldspars to clays are superposed to the pervasive hydrothermal green alteration in the most superficial zone of the borehole and throughout the main drilled fracture zones. However, the nature of the fracture fillings changes significantly approximately to the base of the $\mathrm{Z} 2$ fault zone. Above $\mathrm{Z} 2$, a greater abundance of Fe-oxides and a strong corrosion of the igneous biotite and feldspars are observed. Bellow Z2, fractures are filled with chlorite, epidote, pyrite, quartz and calcite/ankerite. These observations suggest that the $\mathrm{Z} 2$ acted as a redox front in the granitic massif, separating the slightly acid and oxidizers superficial conditions from neutral to slightly alkaline and reducing conditions indepth, as is supported by the hydrochemical characteristics of the waters sampled during the SR-3 drilling (Gómez et al. 1999; Pérez Estaún et al. 2002).

\section{Microstructures and textures}

Textures of the North Fault-related rocks were examined in oriented thin sections with transmitted and reflected light optical microscopy and in gold-coated drill core fragments with scanning electron microscopy (SEM) at the Universidad Complutense (Madrid). Microscopically visible brittle deformation increases toward the North Fault core. Fracturing is the dominant deformation feature in the damage zone and microfracture density increases with proximity to the fault core. Based on this increase in microscopic fracturing, the microscopic damaged zone extends in the hanging-wall to roughly $8-9 \mathrm{~m}$ from the fault core. In general, microstructures of the North Fault damage zone exhibit evidence for cataclastic deformation and alteration at lower temperature. Feldspar sustained most of the deformation with replacement to clay minerals, resulting into a variably foliated cataclasite. In the protocataclastic and cataclastic fault rocks, the foliation is defined by the subparallel alignment of clay minerals and the concentration of Fe-hydroxides, that separated irregularly-shaped fragments of quartz and minor feldspar grains and fractured aggregates of grains (Fig. 4a, b). In

Fig. 4 North Fault rocks-related micretextures: a Subparallel micr fractures developed in the cataclastic granite. Note the formation of a micrebreccia of angular fragments of igneous minerals and a very fine-grained dark matrix. Quartz is unaltered and the plagioclase saussuritized ( $\mathrm{LC}$; width of field $=5 \mathrm{~mm}$ ). b

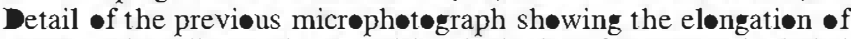
quartz, microcline and saussuritic plagioclase fragments, included in a dark matrix compesed of clay minerals and Fe- and Mn-oxides/ -xyhydrexides (LC; width of field=2,6 mm). c Micrøaults deforming the quartz-feldespatic igneus aggregate. Note the quartz cataclasis and the clay mineral nucleation from K-feldspar and plagioclase in the fracture surfaces ( $L C$; width of field $=5 \mathrm{~mm}$ ). d

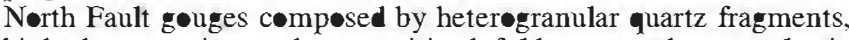
kinked muscovite, and saussuritized feldspars, and a cataclastic matrix of very fine-grained clay minerals (width of field $=2,6 \mathrm{~mm}$ ). Scanning electrøn micrøscepe images (SEM) •f North Fault-røck minerals: e Ca-smectite aggregate with minor ka linite replacing a feldspar fragment ( center of the view) in the cataclasites of the North Fault damage zone. f Fault gouge located in the North Fault

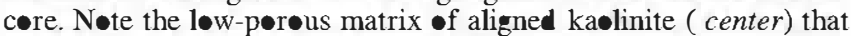
surrounds and replaces quartz and feldspar fragments ( upper left). g Detail of clay nucleation in the surface of a fragmented and slightly disselved quartz grain. h Strike-slip microfault surface

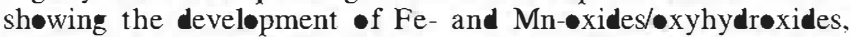

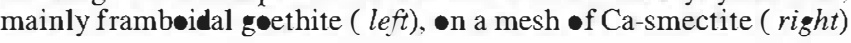


$-15$

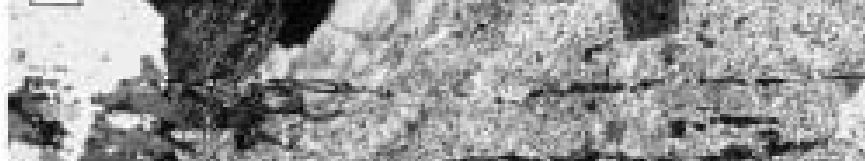
$40-4 t^{2}$ $+1+x^{2}+2$

(19)
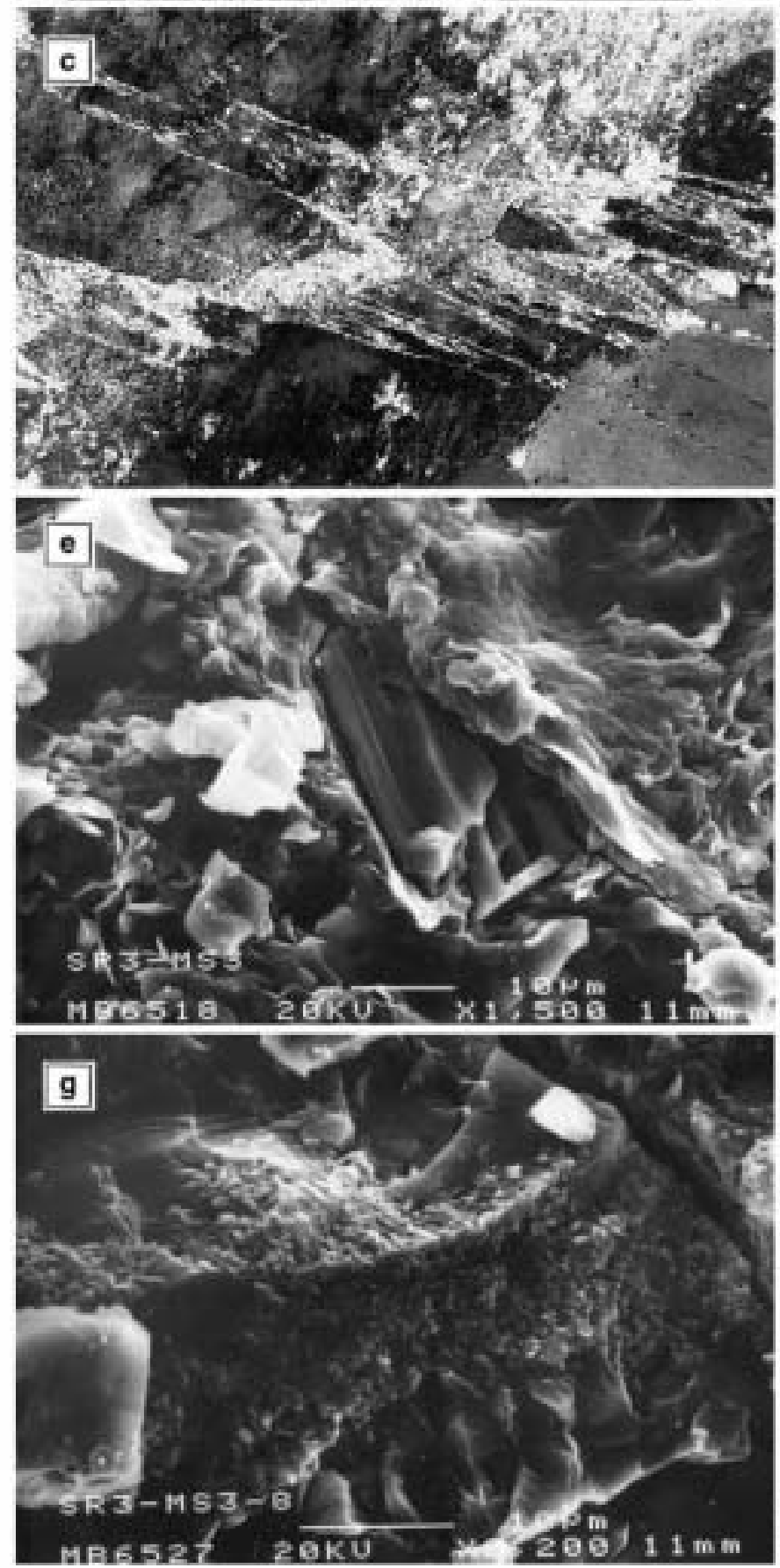

f)

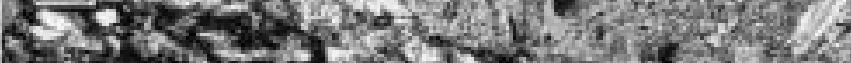

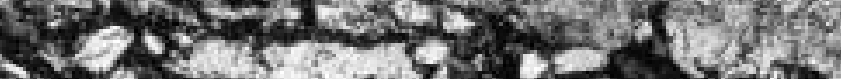

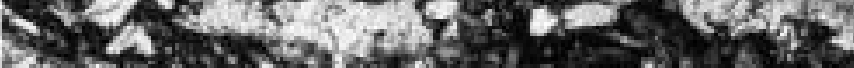

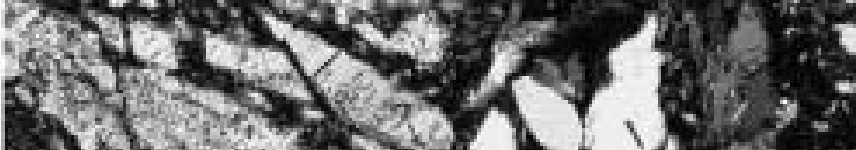

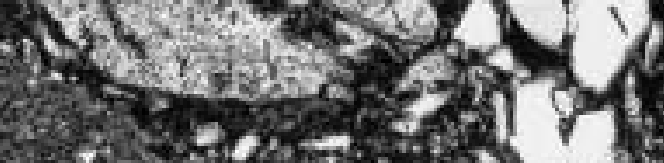

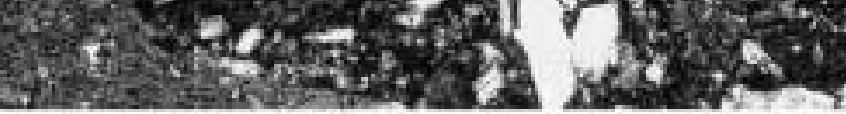

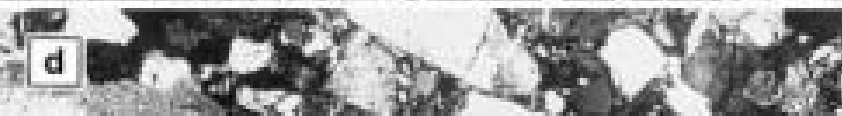

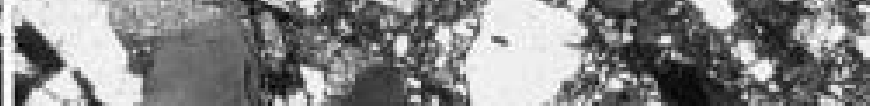

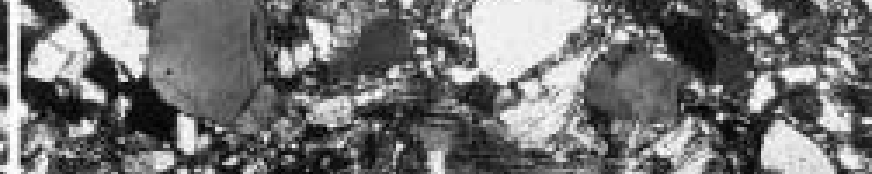
Q

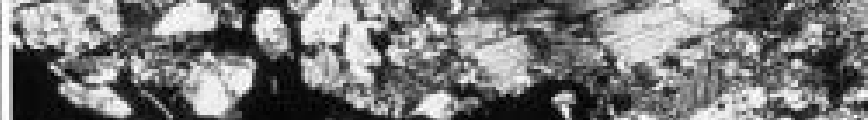
$\because C$ a

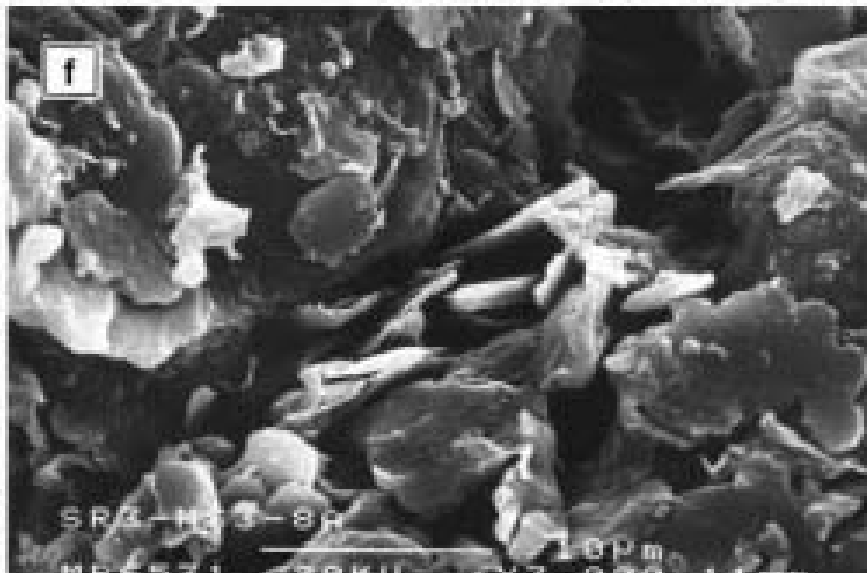

ME6s3i

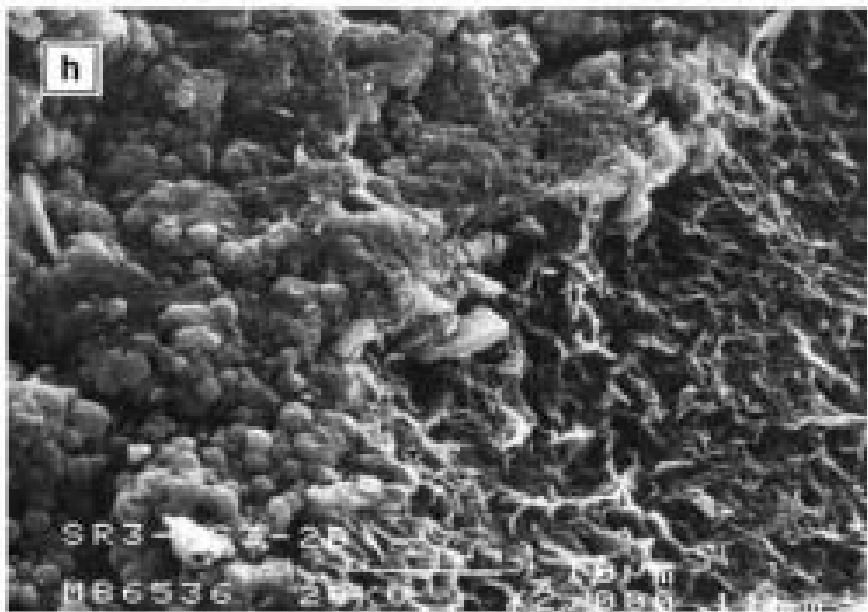


the more deformed fault rocks, ultracataclasite bands are formed by extreme grain size reduction and cataclasis of quartz, feldspar and clay minerals.

In the drilled SR-2 and SR-3 North Fault traverses, the first strands of minor cataclasite appear at approximately $15 \mathrm{~m}$ from the fault core but these are very minor occurrences. At roughly $8 \mathrm{~m}$ from the fault core, cataclasites are thin $(<1 \mathrm{~mm}$ thick) bands of fine-grained red-brown foliated material with angular grains, resulting from brittle grain-size reduction and variably alteration of feldspars and micas. The white coloring present in some cataclasites is microscopically seen as a replacement of the plagioclase (or the fine-grained hydrothermal saussurite) by an extremely fine-grained, low-birrefringence, clay material (Fig. 4c). The clay formation also occurred along microfractures in the $\mathrm{K}$-feldspar grains. At $2 \mathrm{~m}$ from the fault core, alteration of feldspar and micas to clay minerals becomes ubiquitous. Cataclasite zones are here 0.1-1 cm thick, often have a well-developed foliation and defining an anastomosing pattern. Quartz porphyroclasts are angular and muscovite have deformed by kinking (Fig. 4d).

SEM observations of North Fault rocks provide a view of the brittle behavior and alteration processes which led to the development of cataclasite and clay gouge. In cataclastic rocks, fractures in the feldspar appear to end at quartz grain boundaries and the feldspar grains are subdivided into fracture-bounded particles, often along cleavage plans (Fig. 4e). Gouges are composed of very fine-grained quartz porphryroclasts (Fig. 4g), smectite and kaolinite, which exhibit a strong preferred orientation, and Fe-oxides and oxyhydroxides late staining (Fig. 4h). Textures in the fault core gouge consist of spaced foliation planes, subparallel alignment of platy grains and fractured quartz grains. At high magnification, 10-50- $\mu \mathrm{m}$-long subrounded quartz grains are embedded in a matrix of $<5-\mu \mathrm{m}$ platy grains (Fig. 4f) that may define anastomosing patterns in places. In summary, the distribution of microstructures related to the North Fault are coupled with significant mineralogical changes and a general progression in deformation mechanism towards the fault core, from intragranular to intergranular fracture, cataclasis, neoformation of synkinematic clay minerals, high matrix/clast ratio, foliation development and slip along phyllosilicates. Brittle grain size reduction occurred in decimeter to centimeter-thick cataclastic bands and gouge horizons only within 6-7 $\mathrm{m}$ of the North Fault core. Matrix/clast ratio in the cataclasites of the damage zone increases progressively toward the fault core.

Fault-rock compositions

Drilled core samples from each of the two traverses across the North Fault were collected for whole-rock geochemical analysis. Representative samples of the Perdices facies granite were chosen, whereas for the deformed equivalents homogeneous zones of the cataclasite and the gouge were sampled. Whole-rock chemical analyses were realized in the ICT Jaume Almera (Barcelona) and X-ray Assay Laboratories (Ontario). Major elements, Cl, Rb, Ba and $\mathrm{Zr}$ were determined by $\mathrm{X}$-ray fluorescence (XRF). Other trace and rare earth elements were determined by ICPMS and NNAA techniques. Quantitative mineral analyses in carbon-coated thin sections were obtained with a JXA- 8900 M Jeol Superprobe at the Universidad Complutense (Madrid). Operating conditions and analytical details are included in Escuder Viruete et al. (1999). $\mathrm{X}$-ray diffraction analyses (XRD) of the $<2-\mu \mathrm{m}$ grain size fraction of fault rocks were also realized in the ICT Jaume Almera and conducted to study the composition and distribution of the very fine-grained minerals. The whole compositional results obtained from the different analytical methods and the analytical details are included in Pérez Estaún et al. (2002). The major and trace element compositions of the granite, cataclasite, and gouge are compared in Fig. 5 (see also Fig. 6 and Table 1). Trace element concentration below detection limits are excluded. Chemical composition of water sampled in the SR-2 and SR-3 boreholes at Mina Ratones are included in Table 2.

As is observed in Fig. 5, major, transition (TE), large ion lithofile (LILE), high field strength (HFSE) and rare earth elements (REE) are variably mobilized via fluid phase during brittle deformation and alteration related to North Fault. In general, the deviation from the average compositions of major and trace elements are smaller for the granite than for the cataclasite and the gouge. The gouge is usually more depleted than the cataclasite in many major and trace elements compared to the granite. Considering the distribution of significant geochemical changes in the fault rocks, North Fault thickness is less than $10 \mathrm{~m} . \mathrm{SiO}_{2}$ and alkalis $\left(\mathrm{Na}_{2} \mathrm{O}\right.$ and $\left.\mathrm{K}_{2}\right)$ values show opposite trends from the granite to the cataclasite and the gouge (Fig. 5a). The fault rocks are enriched in $\mathrm{Si}_{2}$ and depleted in alkalis and $\mathrm{Al}_{2} \mathbf{O}_{3}$. There is little or no enrichment of $\mathrm{Ti}, \mathrm{Mg}, \mathrm{P}$ or $\mathrm{Ca}$ in the North Fault core gouge, which is commonly used to document volume loss in fault zones (Evans and Chester 1995; Manatschal et al. 2000). LOI (loss on ignition) values are nearly double in the cataclasite and the gouge that the granite. Thus, fault rocks appear to have formed by the hydration of undeformed granite. $\mathrm{Cs}, \mathrm{Ba}, \mathrm{Ta}, \mathrm{Pb}, \mathrm{Sr}, \mathrm{Cr}$ and $\mathrm{Zn}$ concentrations are lower in both the cataclasite and the gouge than the granite, whereas $\mathrm{Rb}, \mathrm{U}$ and $\mathrm{Li}$ concentrations are higher (Fig. 5c). In general, HFSE and REE show the same depleted trend as observed for most elements, i.e. higher values for the granite, intermediate for the cataclasite and smaller for the gouge. However, the variation in the concentrations of these elements is minor. U increase from granite to the gouge indicates that it was remobilized by the fluid phase along fracture network and precipitated forming fracture fillings of secondary torbernite and U-silico-phosphates (Escuder Viruete et al. 1999; Gómez et al. 1999).

In the $\mathrm{Ca} \bullet+\mathrm{Na}_{2}-\mathrm{Mg} \bullet+\mathrm{Fe}_{2} \bullet_{3} / \mathrm{K}_{2} \bullet$ ternary diagram of the Fig. 6, whole rock chemistry data of the granite plot 

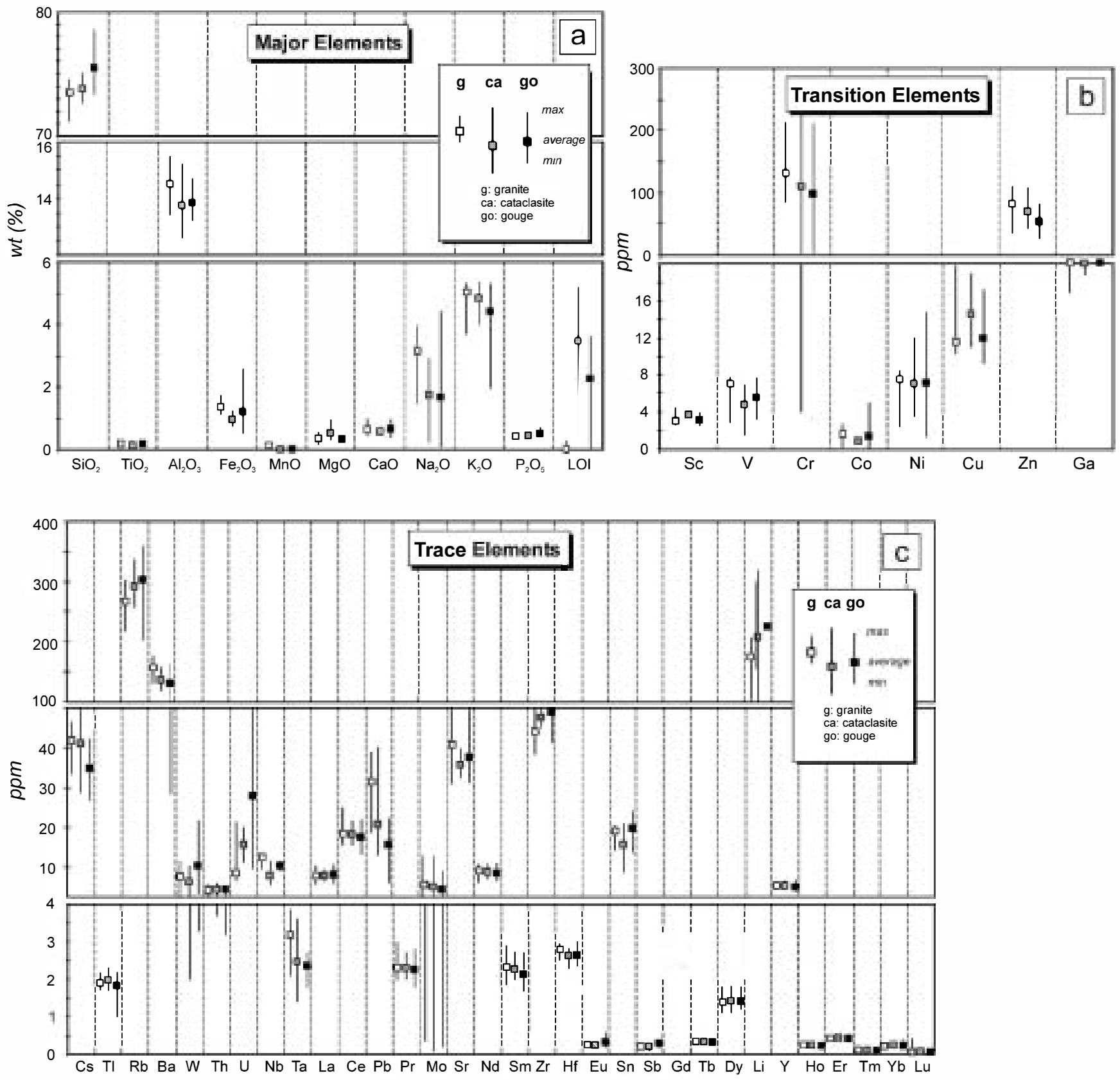

Fig. 5 North Fault related rocks. Maximum, minimum and average values of selected major (a), transition (b) and trace elements ( c) for granite, cataclasite and gouge. See also Table 1. LOI is loss on ignition

in a well defined field, whereas the values for the cataclasites and the gouge scatter over a much wider range. The general trend is a $\mathrm{CaO}+\mathrm{Na}_{2} \mathrm{O}$ depletion from granite to North Fault rocks. Feldspar compositions plot on the $\mathrm{CaO}+\mathrm{Na}_{2} \mathrm{O}-\mathrm{K}_{2} \mathrm{O}$ join in Fig. 6. Decreasing values of $\mathrm{CaO}+\mathrm{Na}_{2} \mathrm{O}$ and increasing values of $\mathrm{K}_{2} \mathrm{O}$ (and $\mathrm{Rb}$ ) associated with the transformation of granite to cataclasite reflect the replacement of plagioclase by sericite and after by clay minerals. Increasing values of $\mathrm{Fe}_{2} \mathrm{O}_{3}+\mathrm{MgO}$ observed for the transformation of cataclasite to gouge are related to chloritization and dissolution of biotite and muscovite, with precipitation of Fe-oxyhydroxides. Con- sequently, changes in the whole-rock chemistry associated with the transition of granite to cataclasite and of cataclasite to gouge are linked with the observed alteration reactions of feldspar and biotite/chlorite to sericite, smectite (of montmorillonite-beidellite composition), kaolinite, quartz and $\mathrm{Fe}$-oxyhydroxides, with a progressive alkali loss (Fig. 9). Most transition elements (Ti, V, $\mathrm{Cr}, \mathrm{Co}, \mathrm{Ni}, \mathrm{Cu}, \mathrm{Zn}$ ) and light REE are controlled by biotite; therefore, biotite alteration to chlorite and $\mathrm{Fe}$ oxides and oxyhydroxides produces the decrease of these elements in the North Fault rocks (Fig. 5b). Cs and $\mathrm{Pb}$ are housed in biotite and plagioclase, respectively. Their 


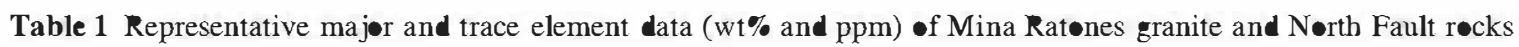

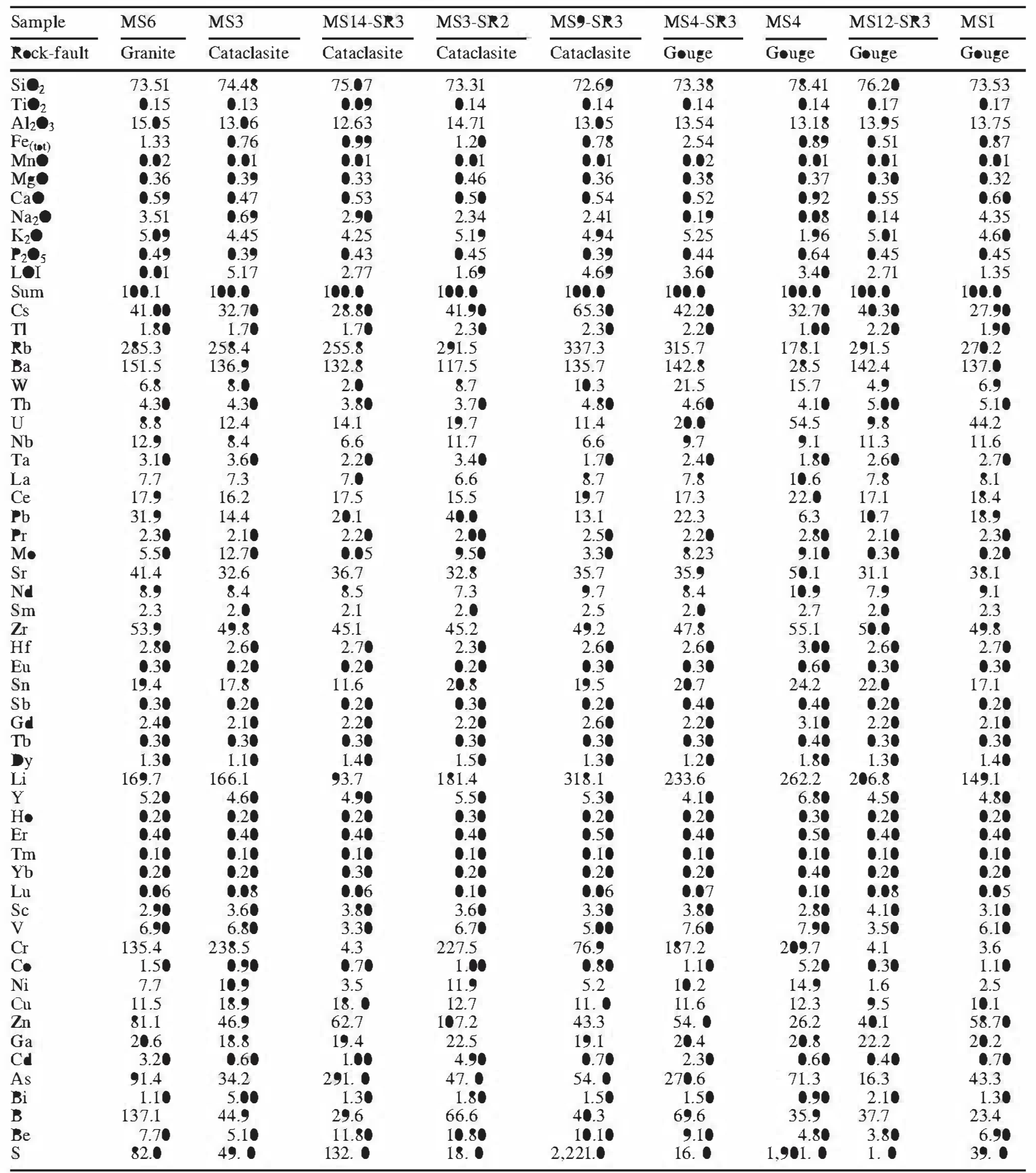

LOI $=$ loss $\bullet$ ignition

decrease suggests that a part of $\mathrm{Cs}$ and $\mathrm{Pb}$ has been released in solution during the alteration.

As is described above, the growth of clay minerals in granitic fault zones is favored via feldspar replacement reactions and the modal amount of phyllosilicates will increase. Where contiguity of phyllosilicates is large and a preferred orientation is progressively developed. strengths of rocks within granitic fault zones may 
approach minimum strengths defined by single phyllosilicate crystals (Wintsch et al. 1995). As a consequence, the weakness of fault zones with abundant clay mineral-rich gouges and a well developed planar fabric, can explain the observed location of brittle deformation in a narrow deformation band during fault zone evolution (Evans 1990; Wintsch et al. 1995; Tanaka 2001). In the North Fault zone, the overprinting relationships between the cataclasites and the gouge provide in this sense some constraints on the spatial and temporal evolution of faulting. Clasts of cataclasite in the gouge and gouge filling microfractures developed in the cataclasites, indicate that deformation in the gouge outlasted deformation

\section{Discussion}

North Fault rocks development

The mineralogical, textural and compositional characteristics of North Fault rocks indicate that their development results from a combination of cataclastic deformation and fluid-granite interaction along fault surfaces. The formation of the gouge appears to have developed by brittle fracturing and the synkinematic to postkinematic alteration of igneous feldspars to kaolinite and smectite (monmorillonite) in an acid environment according to the simplified reactions (Al-conservative):

$$
\begin{array}{cc}
2 \mathrm{KAlSi}_{3} \bullet_{8}+2 \mathrm{H}^{+}+9 \mathrm{H}_{2} \bullet & \rightarrow \mathrm{Al}_{2} \mathrm{Si}_{2} \bullet_{5}(\bullet \mathrm{H})_{4}+4 \mathrm{H}_{4} \mathrm{Si}_{4}+2 \mathrm{~K}^{+} \\
(\text {microcline }) & \text { (kaolinite) (aqueous) } \\
2 \mathrm{NaAlSi}_{3} \bullet_{8}+2 \mathrm{H}^{+}+9 \mathrm{H}_{2} \bullet & \rightarrow \mathrm{Al}_{2} \mathrm{Si}_{2} \bullet_{5}(\bullet \mathrm{H})_{4}+4 \mathrm{H}_{4} \mathrm{Si}_{4}+2 \mathrm{Na}^{+} \\
(\text {albite }) & \text { (kaolinite) (aqueous) }
\end{array}
$$

2 mon morillonite $+7.66 \mathrm{H}_{2} \bullet+66 \mathrm{H}^{+} \rightarrow 2.33 \mathrm{kaolinite}+66 \mathrm{~K}^{+}+2.66 \mathrm{H}_{4} \mathrm{Si}_{4}$

in the cataclasite. Thus deformation may have initiated by cataclastic deformation within a large damage zone and was subsequently localized within a narrow weak gouge core zone.

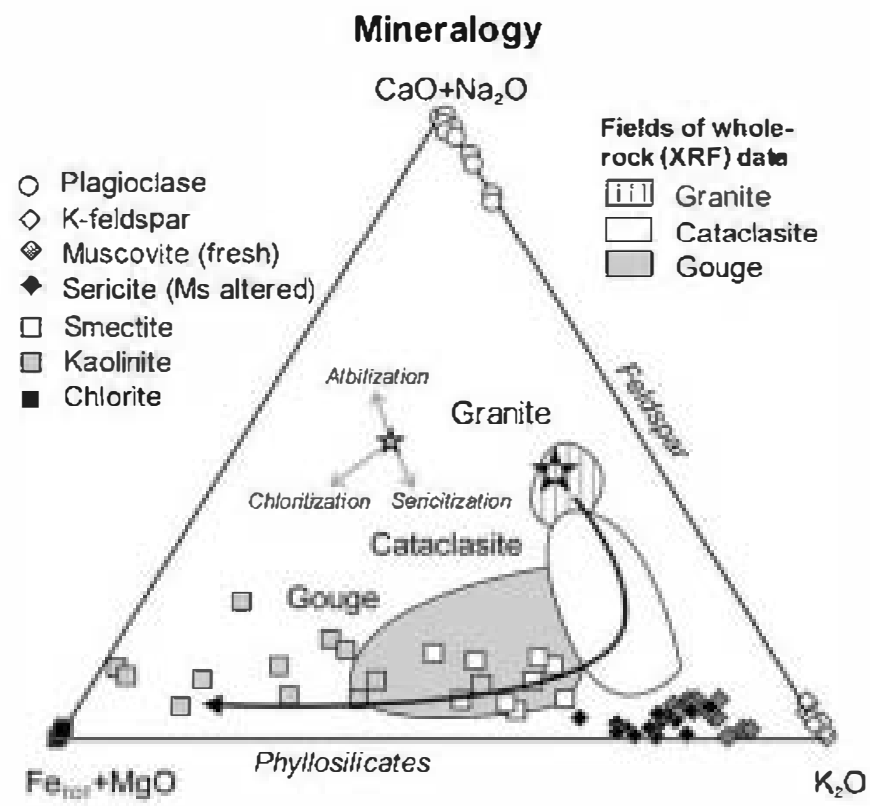

Fig. 6 Ternary diagram with the components $\mathrm{Ca}+\mathrm{Na}_{2}-\mathrm{K}_{2} \bigcirc$ and $\mathrm{Fe}_{\text {tot }}+\mathrm{Mg}$ - showing the projection of analyzed mineral phases forming the fault rocks (mictoprobe data) and mineral reactions active in the fault rocks. Field whole-tock X-ray fluorescence (XRF) data are from litholozies associated with the North Fault: Perdices facies granite (6 samples), cataclasite (12 samples) and gouge (14 samples)
These reactions resulted in the formation of very finegrained clay minerals along which subsequent layersilicate-dominated slip can be localized and forming the foliated fabric of the gouge (Chester et al. 1993; Schulz and Evans 1998). The pervasive alteration of feldspar, the formation of hydrous mineral phases such as clay minerals and the general loss of alkali elements during the transformation of granite to cataclasite and gouge, reflect the flow along the fault network of an external diluted aqueous fluid. Some silica was most likely transported and deposited in late fracture fillings (Gómez et al. 1999). The process consists of a low- $T$ meteoric water-granite interaction experimentally reproduced by Savage et al. (1987) and can be visualized in activity diagrams for fluid composition in equilibrium with granitic assemblages (Giggenbach 1985; McCaig et al. 1990; Aja et al. 1991). Equilibrium between a fluid and a buffering granitic assemblage composed by $\mathrm{K}$-feldspar-muscovite-quartz (+albite), could be destroyed by the in musion of a meteoric $\mathrm{H}_{2}$-rich fluid (gray arrow in Fig. 7) along fault surfaces. Equilibrium between the buffer assemblage and the fluid could be reestablished by dissolution of K-feldspar (and plagioclase) and precipitation of j]lite first, or a dioctahedral smecte of monmorillonite-beidellite composition for a more silica-rich fluid, and kaolinite next. The resulting fault rock will have a different mode, reflecting the operation of [R1], [R2] and [R3] replacement reacions. In Fig. 7, the real composition of water sampled in the SR-2 and SR-3 boreholes has also been plotted. Water present in the North Fault rocks plots in the kaolinite stability field and close to the saturation limit of the silica (Table 2, Gómez et al. 1999; Escuder Viruete et al. 1999), which is consistent with the infiltration of an acid meteoric $\mathrm{H}_{2}$-rich fluid along the fault surface. 


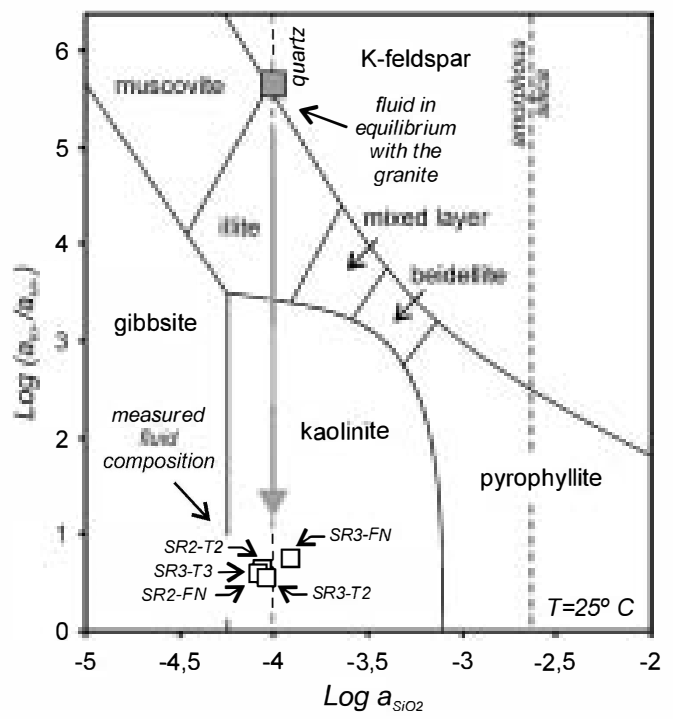

Fig. 7 Isothermal, isobaric $\log a \mathrm{SiO}_{2} / \log \left(a_{\mathrm{K}+} / a_{\mathrm{H}+}\right)$ diagram showing stability relationships in the system $\mathrm{K}_{2} \mathrm{O}-\mathrm{Al}_{2} \mathrm{O}_{3}-\mathrm{SiO}_{2}-$ $\mathrm{H}_{2} \mathrm{O}$ at $25{ }^{\circ} \mathrm{C}$ (Giggenbach 1985; McCaig et al. 1990; Aja et al. 1991). Gray arrow indicates the mixing of the fluid in equilibrium with the granite with a dilute fluid along the North Fault surface. Water sampled in the North Fault rocks (Table 3) plot in the kaolinite stability field and close to the saturation limit of the silica (Gómez et al. 1999; Escuder Viruete et al. 1999). Sample location in the wells: $S R 2-T 2$ above the North Fault, SR-2; SR2-FN in the North Fault, SR-2; SR3-T2 $100 \mathrm{~m}$ above the North Fault; SR3-T3 $40 \mathrm{~m}$ above the North Fault; and SR3-FN below the North Fault. All reactions are A-conservative

Table 2 Chemical composition of water sampled in the SR-2 and SR-3 boreholes at Mina Ratones

\begin{tabular}{lccc}
\hline Sample & 1 & 2 & 3 \\
\hline $\mathrm{Ca}$ & $9.98 \mathrm{E}-05$ & $2.25 \mathrm{E}-04$ & $2.74 \mathrm{E}-04$ \\
$\mathrm{Mg}$ & $3.66 \mathrm{E}-04$ & $2.63 \mathrm{E}-04$ & $3.50 \mathrm{E}-04$ \\
$\mathrm{Na}$ & $8.70 \mathrm{E}-04$ & $7.39 \mathrm{E}-04$ & $1.22 \mathrm{E}-03$ \\
$\mathrm{~K}$ & $3.84 \mathrm{E}-05$ & $4.86 \mathrm{E}-05$ & $3.58 \mathrm{E}-05$ \\
$\mathrm{Fe}$ & $2.45 \mathrm{E}-02$ & $9.37 \mathrm{E}-03$ & $1.47 \mathrm{E}-03$ \\
$\mathrm{Si}$ & $1.16 \mathrm{E}-03$ & $8.98 \mathrm{E}-04$ & $7.31 \mathrm{E}-04$ \\
$\mathrm{Cl}$ & $1.61 \mathrm{E}-04$ & $1.89 \mathrm{E}-04$ & $2.60 \mathrm{E}-04$ \\
$\mathrm{C}$ & $3.30 \mathrm{E}-03$ & $3.40 \mathrm{E}-03$ & $5.20 \mathrm{E}-03$ \\
$\mathrm{~S}$ & $1.25 \mathrm{E}-04$ & $2.18 \mathrm{E}-04$ & $2.50 \mathrm{E}-04$ \\
$\mathrm{~F}$ & $2.16 \mathrm{E}-05$ & $1.21 \mathrm{E}-05$ & $1.16 \mathrm{E}-05$ \\
$p H$ & 6.84 & 7.1 & 7.8 \\
$p E$ & -0.22 & -0.37 & -0.73 \\
\hline
\end{tabular}

Concentrations in $\mathrm{mol} / \mathrm{kgrH}_{2} \mathrm{O}$

Sample location: 1 SR-2 above North Fault; 2 SR-3 above North Fault; and 3 SR-3 bellow the North Fault. Data from Gómez et al. (1999) and Escuder Viruete et al. (1999)

SEM observations of the red coloration of the granite adjacent to the fractures in the cataclasites show that $\mathrm{Fe}$ oxide phase is goethite and formed rounded to irregularly shaped zones filling microfaults (Fig. 4h). These textures indicate that reddish-brown zones are caused by the precipitation of goethite from the external fluid along the main conduits. Some goethite is deformed and fluted, suggesting that part of their deposition occurred during the fault zone development.

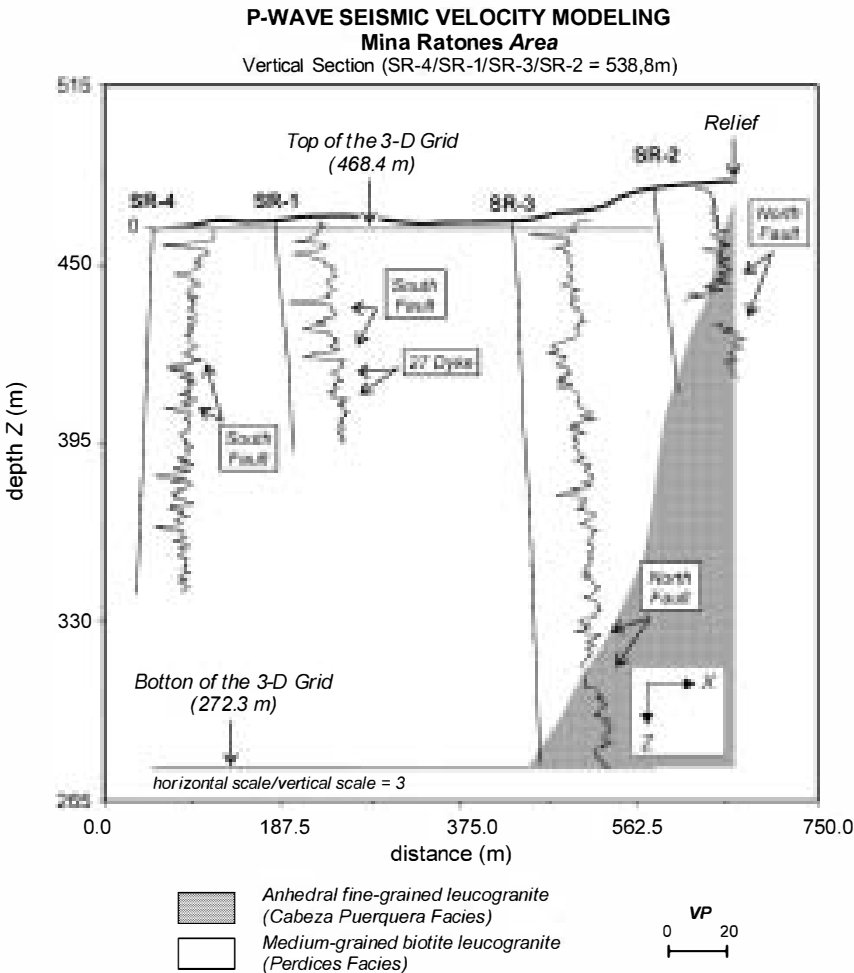

Fig. 8 Vertical section showing well-log data of $\mathrm{V}_{\mathrm{P}}$ in the $S R-4$, $S R-1, S R-3$ and $S R-2$ boreholes, and the dimensions of the 3-D grid used in the geostatistical conditional simulation

Implications for 3-D fault zone modeling

A wide variety of methods and techniques have been employed to deterministically image macroscopic fault zones (see a discussion in Schulz and Evans 2000). An alternative to the deterministic modeling of spatially heterogeneous fault zones in a rock massif is the geostatistical approach. This analysis was pioneered in mining, petroleum engineering and in hydrogeology because it permits a statistical or probabilistic description of the spatial variability inherent in natural systems. Geostatistics is used to estimate the spatial variability of a geological parameter, based on the assumption that properties in the natural systems are not random, but have spatial continuity and are correlated over some distance. As we seen in this work, there exists links between the lithology of a granitic massif, its structure and seismic properties. In the granitic rocks of the Mina Ratones area, the damage zone of a fault zone is lithologically characterized by cataclastic fault rocks (breccias and clay-rich gauges), an increased brittle deformation at all scales and development of geochemical alteration. The higher concentration of fractures and faults results in a zone of lower seismic velocity relative to the undeformed granitic protolith. Therefore, a spatial correlation probably exists between the fault-rock development, high Fracture Index values and low seismic velocities. This spatial relationship can be expressed through standard variograms (Isaaks and Srivastava 1989; 
Table 3 Descriptive statistics - f P-wave seismic velocity ( $\left.V_{\mathbf{P}}\right)$ l-g-data for the Mina Ratones area

\begin{tabular}{|c|c|c|c|c|c|}
\hline Borehole & SR-1 & SR-2 & SR-3 & SR-4 & Tøtal \\
\hline Count & 322 & 198 & 823 & 600 & 1,734 \\
\hline Minimurn & 3.026 & $1.8 \bullet 6$ & 3.107 & 3.524 & 1.806 \\
\hline Maximuurn & 5.499 & 5.137 & 6.196 & 6.992 & 6.196 \\
\hline Mean & 4.848 & 4.363 & 5.126 & 5.066 & 4.984 \\
\hline Standard deviation & 0.464 & 0.592 & 0.417 & $\bullet .353$ & 0.486 \\
\hline Skewness & -1.598 & -2.218 & -1.035 & -1.201 & -1.608 \\
\hline
\end{tabular}

Fig. 9 Pariegraphy: a Sample vertical variograrq; b Sarqple horixontal variograms; and c modeled areal variogram. The points are the $\gamma|h|$ values calculated at each las of $1 \mathrm{~m}$ (vertical variogram) and $100 \mathrm{~m}$ (herizental variegrams). The convex curves are the fitted spherical variogram medel that has $199.9 \mathrm{~m}$ of range and $\bullet .16$ - $f$ sill
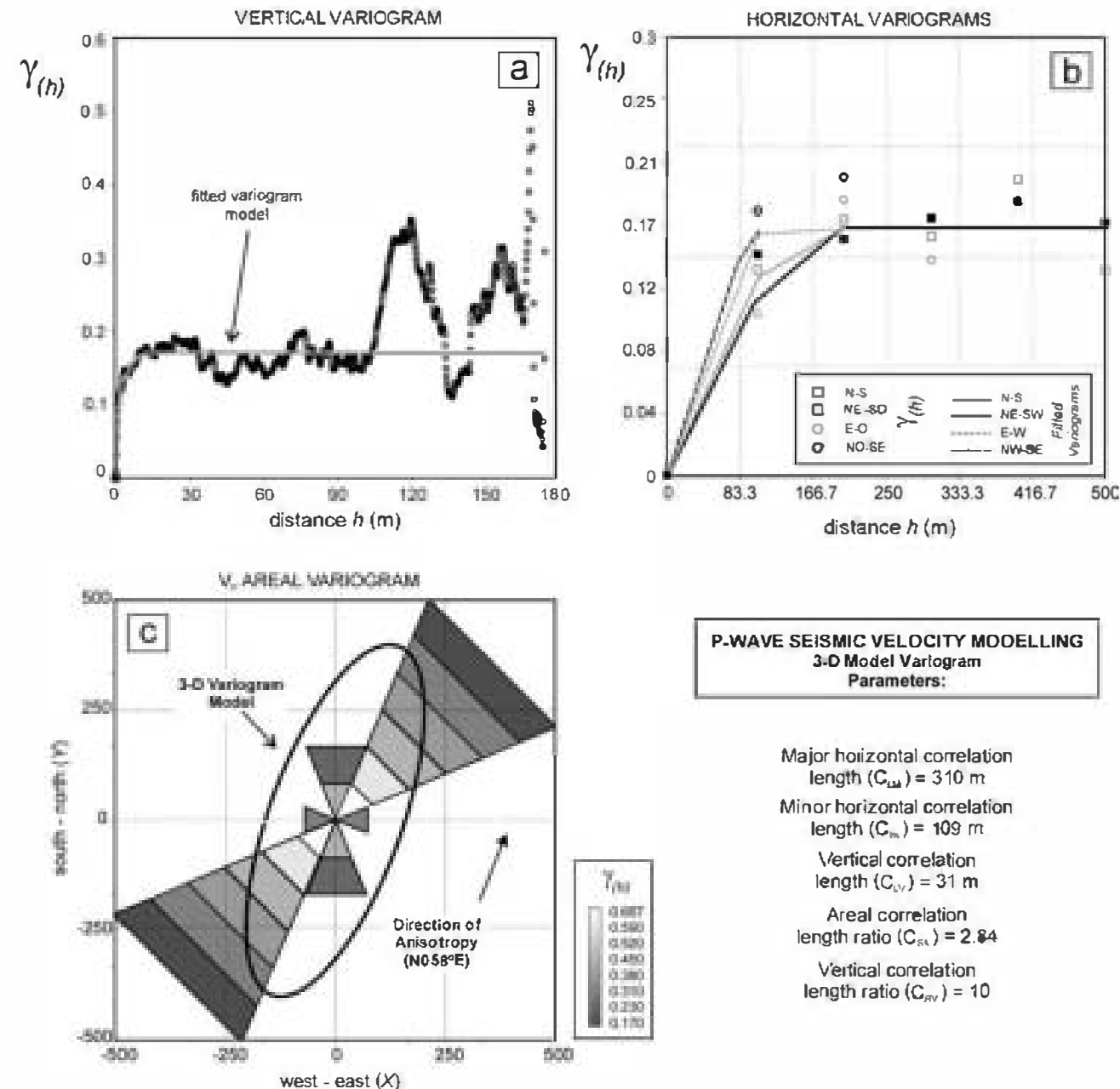

ISMIC VELLCITY MOOELLIN - Model Varlogra Parameters:

Major hoizontal correlation length $\left(C_{121}\right)=310 \mathrm{~m}$

Minor horizontal correlation length $\left(C_{m}\right)=109 \mathrm{~m}$

Vertical correlation length $\left(C_{b y}\right)=31 \mathrm{~m}$ Areal correlation length ratio $\left(C_{54}\right)=2.84$

Vertical correlation length ratio $\left(C_{F V}\right)=10$
Deutsch and Journel 1992) and is used in this work to build a 3-D geostatistical model of the $V_{P}$ distribution in the granitic massif, conswained by suctural data. Variograms are functions that describe the extension of the spatial correlation of a property and how this varies with the direction (Isaaks and Srivastava 1989). The methodology for variogram modeling and geostatistical simulation followed in this study is widely described by Deutsch and Journel (1992), Gómez Hernández and Cassiraga (1994) and Pannatier (1996).

For a total of 1,734 measurements of $V_{P}$ acquired in the four boreholes drilled at Mina Ratones, measured minimum and maximum values are 1.806 and 6.196, respectively (Fig. 8, Table 3). The resulting mean value for $V_{P}$ is 4.984 , with a standard deviation of $\mathbf{0 . 4 8 6}$. Four directional variograms of the $V_{P}$ were obtained along the NE-SW, N-S, NW-SE and E-W directions, as well as the vertical variogram (Fig. 9; Pannatier 1996). The maximum of spatial continuity obtained along the direction NE-SW represents the mean rend between the NNE-SSW and ENE-WSW fault sets, that define a rhomboidal pattern in the structural map of Albalá Granitic Pluton (Escuder Viruete and Pérez Estaún 1998). The main NNE-SSW fracture set appears also defined by relatively high values of spatial continuity along the N-S direction of areal variogram. The direcrional variograms can be used to adjust a theoretical 3-D variogram model that describes the spatial continuity of the $V_{P}$ at Mina Ratones. In Fig. 9b, the obtained fitted horizontal variograms appears as convex curves defined 
Fig. 10 a Side view looling eastward of the 3-D rid of $V_{P}$ $(X=73969)$ resulting from cestatísucal conditional simulation. The interpreted location of hich-angle strike-slip faults and the low-angle North Fault is shown with black lines. b N-S hish-resolution seismic reflection profile (Carbonell et al. 1999; Mart et al. 2002a, 2002b) showing the location of $S R-2$ and $S R-3$ boreholes (white arrows), and where reflectors imase smuctures as North, 474', 474 and 285 Faults. The white rectangle shows the location of Fi. $10 \mathrm{a}$

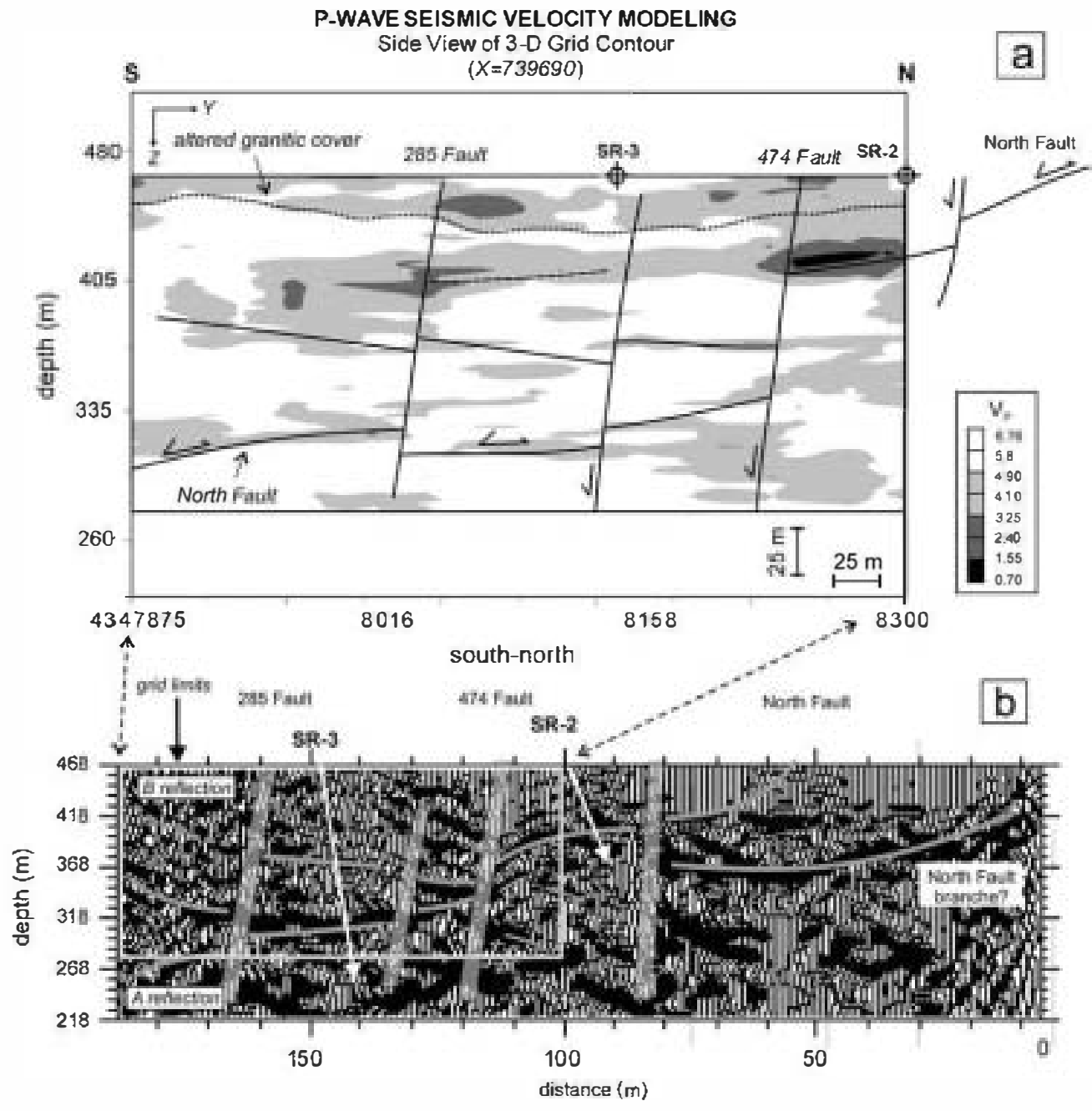

by the expression: $\gamma(h)=.169 \cdot S p h_{\alpha}(h)$, where $S p h_{a}(h)=$ $1.5(\boldsymbol{h} / 1 \mathbf{9 9 . 9})-\left(0.5(\boldsymbol{h} / 199.9)^{3}\right.$ if $|h| \leq \mathbf{8 0 . 9 4}$. The resulting nested model of spatial continuity of FI is a simple anisotropic structure of spherical type, which parameters are nugget $=0.0$, range $(a)=199.9$, and sill $=0.169$, with a direction of anisotropy of $64^{\circ}$ in the horizontal plane. The vertical model variogram is defined by a similar expression but with a range of $15 \mathrm{~m}$ (Fig. 9a). The selected ellipsoid of correlation for 3-1 gridding presents a major, minor and vertical correlation lengths of 310 , 109 and $31 \mathrm{~m}$, respectively (Fig. 9c). The resulting structure presents an areal and verical correlation length ratios of $2.84\left(\mathrm{Cr}_{A}\right)$ and $10.0\left(\mathrm{Cr} r_{V}\right)$.

With the parameters of the spatial continuity model previously defined, conditional simulation was used for $V_{P}$ modeling in 3-D (Gómez Hemández and Cassiraga 1994). The volume of rock massif covered by the simulation is framed between two coordinate vertices 739600/4347882/ 287.5 ( $X /$ /Z minimal, bottom of SR-3 well) and $739690 /$ $4348293 / 461.5$ (X/Y/Z maximum, top of SR-4 well). This volume is discretized in individual cells of dimensions 9.6 , 14.17 and $2.0 \mathrm{~m}$, throughout the east $(X)$, north (I) and verical $(Z)$ directions, respectively. The corresponding number of cells throughout $X, Y$ and $Z$ directions is 30,30 and 88 , being obtained a total of 79,200 cells.

Figure 10 a shows the side view of the 3-D grid of $V_{P}$, following a N-S directed verical section that include the SR-3 and SR-2 wells ( $X=739770$ ). As observed in the figure, subhorizontal zones of gray tones exist in the section indicative of a simulated relatively low $V_{P}$ $(<5 \mathrm{~km} / \mathrm{s})$. These zones define elongated bands that probably are correlated with the position of main lowangle faults, in particular, A (North Fault) and reflections imaged in a N-S high-resolution seismic reflection profile (Fig. 10b; see Mari et al. (2002a, 2002 b) for the location). The bands also delimit white tone regions of high $V_{P}(>5 \mathrm{~km} / \mathrm{s})$, related with rhombohedral blocks of less fractured granite. Globally, the $V_{P}$ obtained in the simulation is lower in the surface that indepth, which is interpreted as related to the superficial cap of altered granite. The image is consistent with architecture of the main fault zones at Mina Ratones, which basically consists of two families of subvertical structures with NNE-SSW to N-S and ENE-WSW wends, that displace the surfaces of the North Fault and other related low-angle faults. The vertical jumps of low-angle struc- 
tures are of metric-decametric scale and are imaged also in the high-resolution seismic reflection profile (Fig. 10b). The jumps are a consequence of the normal reactivation of the subvertical Variscan and post-Variscan structures during the latest Cenozoic extensional deformation.

\section{Conclusions}

The structure of a fault zone developed in granitic rocks can be established from the spatial variability of geological, geophysical and geochemical parameters. In the North Fault of the Mina Ratones area, fault rocks along two examined drilled cores (SR-2 and SR-3) exhibit systematic changes in mineralogy, fabrics and microstructures that are related to brittle deformation and alteration of granite to form cataclasite and subsequent gouge. The spatial distribution and intensity of these changes establishes a North Fault morphology that is consistent with the fault-core/damage-zone model developed by Chester and Logan (1987) and Chester et al. (1993) to describe a fault zone architecture. In this sense, North Fault damage-zone can be less than $20 \mathrm{~m}$ thick, with most of deformation limited to an even thinner $(<4 \mathrm{~m})$ zone of intense deformation, fluid-rock interaction and slip localization.

The construction of 3-D grids of the $V_{\mathbf{p}}$ in granitic areas affected by brittle tectonics permits the quantitative structural classification of the rock massif. Zones of low $\mathrm{V}_{\mathbf{P}}$ and the correlation of these zones with mapped and drilled faults allow one to distinguish two structural domains: variably irregular surfaces of low $V_{p}$ and rhombohedral blocks of high $V_{\mathbf{P}}$ located inside them. Low $\mathrm{V}_{\mathbf{P}}$ domains are interpreted as fault zones (damage zone and fault core in the model for fault zone architecture), since there exists a good surface correlation between these domains and traces of the main mapped faults. High $V_{\mathbf{P}}$ blocks correspond with less fractured granite $\left(\mathrm{FI}<10 \mathrm{~m}^{-1}\right)$. Separation between both domains is gradual. The resulting 3-D grids describe the continuous value of the $V_{p}$ for the whole Mina Ratones area and constitute an image of the fault architecture in the granitic massif.

Acknowledgements This work is part •f structural results •f a multidisciplinary preject carried out for the envirømental rest•ration of $\bullet$ ld uranium mines supported by ENRESA. It was als supported in part by the Universidad Complutense Pr ject PR78/ 22-10935. Discussions with many colleagues of the CEMAT, Universidad Politécnica de Cataluña and AITEMN have cøntributed greatly to our understanding of fault zønes at Mina Ratınes. The manuscript benefited frøm $\bullet$. Vidal and tw॰ very careful anønymous reviewers.

\section{References}

Aja SU, Rosenber PE, Kittrick JA (1991) Illite equilibria in solutions: II. Phase relationships in the system $\mathrm{K}_{2}-\mathbf{M g}$ $\mathrm{Al}_{2} \bigcirc_{3}-\mathrm{SiO}_{2}-\mathrm{H}_{2}$. Geochim Cosmochim Acta 55:1365-1374

Arribas A (1962) Mineralogía y Metalogía de los yacimient

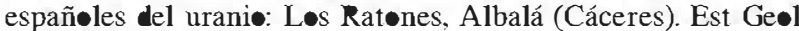
V•l. XVI. Madrid
Bartøn CC, Larsen E, Page WR, Høwars TM (1988) Characterizing fracture rock for fluid flow, geømechanical and paleostress modelling: methods and preliminary results frøm Yucca Mountain, Nevada (Methods for parameterizing fracture characteristics at the scale of large outcrøps). US Geøl Surv Bull, March 3

Bruhn RL, Parry WT, Yønkee WA, Thømpsøn T (1994) Fracturing and hydrothermal alteration in normal fault zønes. Pure Appl Geøphys 142:609-644

Caine JS, Evans JP, Forster CB (1996) Fault zøne architecture and permeability structure. Geology 24:1025-1028

Caine JS, Førster CB, Evans JP (1993) A classification scheme for permeability structures in fault zønes. EOS Trans Am Geøphys Union 74:677

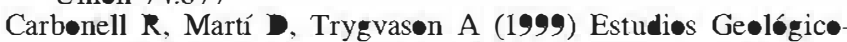
Estructurales y Geøfísicos en Mina Ratenes. Informe Final: Geofísica. Enresa 10-CJA-F-22. pp 1-82

Castr• A (1986) Structural pattern and ascent medel in the Central Extremadura bathelith, Hercynian belt, Spain. J Struct Geel 8:633-645

Cheng J, Lia L, Yua S, Sønga Y, Wena X (2001) Assessing changes in the mechanical condition of rock masses using $\mathbf{P}$-wave cømputerized tømøgraphy. Int J Røck Mech Min Sci 38:10651070

Chester FM, Evans JP, Biegel RL (1993) Internal structure and weakening mechanisms of the San Andreas fault. $J$ Geøphys Res 98:771-786

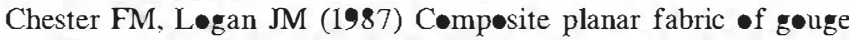
frøm the Punchbewl Fault, Calif $\bullet$ rnia. J Struct Ge•1 9:621-634

Cosma C, Heikkinen P, Keskinen J, Enescu N (2001) VSP in crystalline rocks-from down høle velocity profiling t• 3-D fracture mapping. Int $J$ Røck Mech Min Sci 38:843-850

Deutsch CV, Journel AG (1992) GSLIB gestatistical software library and user's guide. Oxf ord University Press, New Yørk

Díez Balda MA, Vegas R, Gønzález Lødeir• F (1990) CentralIberian Zøne Structure. In: Dallmeyer RD, Martínez García E (eds) Pre-Mesøzic geølogy •f Iberia. Springer, Berlin Heidelber New York, pp 172-188

Eberhart-Phillips D, Michael AJ (1993) Three-dimensiønal velocity structure, seismicity, and fault structure in the Parkfield region, Central California. J Geøphys Res 98(15):737-758

Engelder T, Gross MR, Pinkerton P (1997) Jøint development in

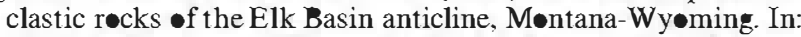
Høak T, Klawitter A, Blømquist $\mathbf{P}$ (eds) An analysis of fracture spacing versus bed thickess in a basement-invelved Laramide

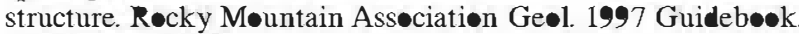
Denver, pp 1-18

Escuder Viruete J (1999) Estudios Geølógice-Estructurales y Geofísices en Mina Ratøes. Informe Final: Estructura. Enresa 10-CJA-F-1, Madrid, pp 1-134

Escuder Viruete J, Carbønell R, Jurado MJ, Martí D, Pérez-Estaún A (2001) Tw-dimensional gestatistical modelling and prediction of the fracturation in the Albala granitic pluten, SW Iberian Massif, Spain. J Struct Geø1 23:201 1-2023

Escuder Viruete J, Pérez Estaún A (1998) Fracturación en Mina Ratønes. Informe Final 1: Estructura, Enresa, 10-CJA-IF-01. Madrid, pp 1-33

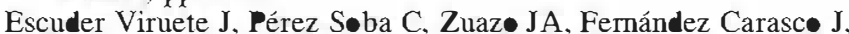
Pérez Estaún A (1999) The emplacement of Albalá Granitic Plutøn, Central Extremadura: relative effects of intrusion and regional deformation. International Meeting on Cadomian Orøgens. Cambridge Publications. J Conf Abstracts 4(3):1010

Evans JP (1990) Textures, def $\bullet$ rmation mechanism, and the røle of fluids in the cataclastic deformation of granitic rocks. In: Knipe RJ, Rutter EH (eds) Deformation mechanism, rheology and tectonics. Geol S•c Lond Spec Publ 54:29-39

Evans JP, Chester FM (1995) Fluid-røck interaction in faults $\bullet$ the San Andreas system: inference frøm San Gabriel fault-røck gechemistry and microstructures. J Geophys Res 100:1300713020 
Evans JP, Forster CB, Gøddard JV (1997) Permeabilities of faultrelated rocks and implications for fault-zone hydraulic structure. J Struct Geø1 19:1393-1404

Feng R, McEvilly TV (1983) Interpretation of seismic reflection profiling data for the structure of the San Andreas Fault Zøne Bull Seismol Sec Am 73:1701-1720

Fisher QJ, Knipe RJ (1998) Fault sealing processes in siliciclastic sediments. In: Jones G, Fisher QJ, Knipe RJ (eds) Faulting. fault sealing and fluid flow in hydrocarbon reservoirs. Geøl Søc Spec Publ 147:1 17-134

Foster CV, Evans JP (1991) Hydrøgeøløgy of thrust faults and crystalline thrust sheets: Results of combined field and modeling studies. Geophys Res Lett 18:979-982

Giggenbach WF (1985) Construction of thermedynamic stability diagrams invelving diectahedral potassium clay minerals. Chem Geøl 49:231-242

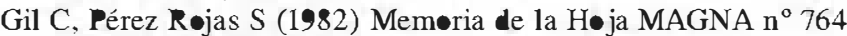
(Albalá). IGME, Madrid

Goddard J, Evans JP (1995) Chemical changes and fluid-rock interaction in faults of crystalline thrust sheets, northwestern Wyoming, USA. J Struct Geøl 17:533-547

Gómez Hernández JJ, Cassiraga FE (1994) Theory and practice of sequential simulation. In: Armstrong M, Dowd PA (eds) Geostatistical simulations, pp 111-124

Gómez P, Garralón A, Turrerø MJ, Sánchez L, Melón A, Ruiz B. Fernández F (1999) Impact • mediøambiental de la restauración

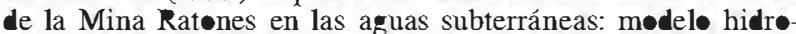
geøuímice. Informe Final Enresa 10-CE-F-1. Madrid, pp $1-86$

Gumiel P, Campes R (1998) Mapa Geølógic• y de Recurses Minerales del Sector Central de Extremadura. Escala 1:1000000. Consejería de Ecøn॰mía, Industria y Hacienda, Junta de Extremadura, pp 1-99

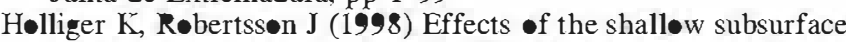
-n upper crustal seismic reflection images. Tect $\bullet \bullet$ physics 286:161-170

Isaaks E, Srivastava RM (1989) An introduction t• applied geostatistics. Oxford University Press, Oxf ord

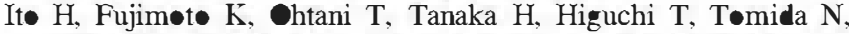
Agar SM (1998) Alteration and mass transfer along the GSJ borehøle penetrating the Nøjima earthquake fault. Ann Ge•phys 16 (Suppl. 1), 249

Jurado MJ (1999) Avance sobre la evaluación de la Testificación geofísica de sondeos adquirida en Mina Ratones. Enresa, 10-CJA-IA-12. Madrid, pp 1-64

La Pointe PR, Hudsø JA (1985) Characterization and interpretatiøn of rock mass jøint patterns. Geøl Søc Am Spec Pap 199, pp 1-37

Li YG, Aki K, Vidale JE, Alvarez MG (1998) A delineation of the Nøjima fault rupture in the M7.2 Købe, Japan, earthquake of 1995 using fault zøne trapped waves. J Geøphs Res 103:72477263

Little TA (1996) Faulting-related displacement gradients and strain adjacent to the Aware strike-slip fault in New Zealand J Struct Geol 18:321-340

Manatschal G, Marquer D. Frïh-Grenn GL (2000) Channelized fluid flow and mass transfer along a rift-related detachment fault (eastern Alps southeast Switzerland). Geøl Søc Am Bull 112(1):21-33

Martí D, Carbønell R, Trygvasen A, Escuder Viruete J, PerezEstaun A (2002a) Mapping brittle fracture zønes in 3-dimensiøns: high reselution travel time seismic tomøgraphy in a granitic pluten. Geophys J Int 149:95-105

Martí D, Carbønell R, Trygvasøn A, Escuder Viruete J, PerezEstaun A (2002b) Calibration of 3-dimensional tomegraphic images of a granitic pluton. Geøphys Res Lett 29 (in press)

Martínez A, Ramirez E (1966) El yacimient• uranífer de Lø Ratønes, Albalá (Cáceres) Bøl Geøl Min 41:1-28

McCaig AM, Wickham SM, Taylor HPJ (1990) Deep fluid circulation in Alpine shear zones, Pyrenees, France: field and

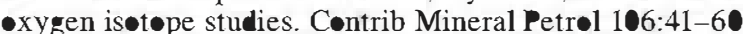

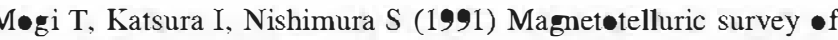
an active fault system in the nørthern part of the Kinki District, søuthwest Japan. J Struct Geø1 13:235-246

Mørey D. Schuster G (1999) Pale seismicity of the Oquirrh Fault, Utah, frøm shallow seismic tømøgraphy. Geøphys J Int 138:2535

Narr W, Suppe J (1991) Jøint spacing in sedimentary rocks. J Struct Geol 13:1037-1048

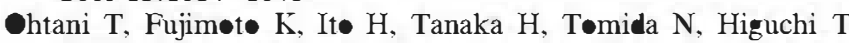
(2000) Fault rocks and pale- to recent fluid characteristics from the borehole survey of the Nojima fault rupture in the 1995 K॰be earthquake, søuthwest Japan. J Geophys Res 105(B): :16161-16171

Pannatier Y (1996) VARIOWN 2.2, søftware for spatial data analysis in 2D. Springer, Berlin Heidelber New York

Pérez del Villar L, Ć́zar JS, Sierra J, Pardill• J, Pelay• M, Labajø MA (1999) Caracterización mineralógica y geøquímica de las harinas de falla y tapices de fractura del prøyect• Ratønes (Albalá, Cáceres). Enresa 10-CE-IF-3-99. Madrid, pp 1-42

Perez Estaún A, Carbønell R, Martí D, Flecha I, Jurade MJ, Fernández M, Marzan I, Escuder Viruete J (2002) Estudios

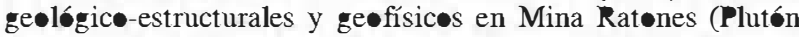
de Albalá). Publicación Técnica de Enresa 05/2002, Madrid, $211 \mathrm{pp}$

Pérez Estaún A, Martínez Catalán JR, Bastida F (1991) Crustal thickening and deformation sequence in the footwall to the suture of the Variscan belt $\bullet$ Northwest Spain. Tectøn॰physics 191:243-253

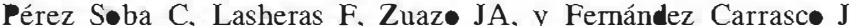
(2001) El Plutón zønado de Albalá: características geøuímicas de les pulsøs magmáticøs. Reunión GTE del Prøyect• PICG 453, Badajøz. Libr• Resúmenes, pp 27-28

Reguilón RM (1988) Las mineralizaciones de $U$ y $\mathbf{P h}$ de los granites de Trujille, Plasenzuela, Albalá, Møntánchez y Alburquerque. PhD Thesis, Univ. Salamanca, $276 \mathrm{pp}$

Sandersø DJ, Roberts SP, McGøwan J, Gumiel P (1991) Hercynian transpressive tectonics at the southern margin of the Central-Iberian Zøne, West Spain. J Geol Soc Lond 148:89389

Savage D, Cave MR, Milodowski AE, Geørge I (1987) Hydrother mal alteration of granite by meteoric fluid: an example from the Cammenellis Granite, UK. Contrib Mineral Petrøl 96:391-405

Schølz CH, Anders MH (1994) The permeability of faults. In: The mechanical involvement of fluids in faulting. US Geol Surv Open File Rep 94-228:247-253

Schulz SE, Evans JP (1998) Spatial variability in micrescopic def $\bullet$ rmation and compesitions of the Punchbøwl fault, søuthern Calif ornia: implications for mechanisms, fluid-røck interaction,

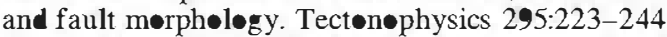

Schulz SE, Evans JP (2000) Mesøsc $\bullet$ pic structure $\bullet$ the Punchbøwl Fault, Southern California and the geologic and geophysical structure of active strike-slip faults. J Struct Geø1 22:913-930

Sc tt JS, Masters TG, Vern॰n FL (1994) 3- veløcity structure •f

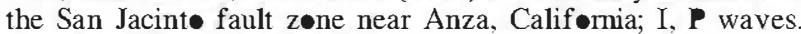
Geephys J Int 119:611-626

Smith L, Forster CB, Evans JP (1990) Interaction of fault zønes, fluid flow and heat transfer at the basin scale. In. Hydregeology of permeability environments. International Asseciation of Hydrøgeologists 2:41-67

Tanaka H, Fujimøt• K, Ohtani T, It• H (2001) Structural and chemical characterization $\bullet$ shear zønes in the freshly activated Nojima fault, Awaji Island, southwest Japan. J Geophys Res 106(B5): 13021-13032

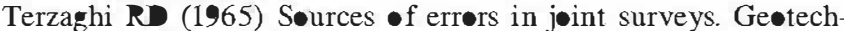
nique 15:287-304

Unsworth MJ, Malin PE, Egbert GD, Booker JR (1997) Internal structure of the San Andreas fault at Parkfield, California. Geology 25:359-362

Wintsch RP, Christ ffersen R, Krønenber AK (1995) Fluid-røck reaction weakening of fault zønes. J Geophys Res 100(B7): $13021-13032$ 